\title{
Cancer Incidence in Egypt: Results of the National Population-Based Cancer Registry Program
}

\author{
Amal S. Ibrahim, ${ }^{1}$ Hussein M. Khaled, ${ }^{2}$ Nabiel NH Mikhail, ${ }^{3}$ \\ Hoda Baraka, ${ }^{4}$ and Hossam Kamel ${ }^{2}$ \\ ${ }^{1}$ Department of Biostatistics and Cancer Epidemiology, National Cancer Institute, Cairo University, Cairo, Egypt \\ ${ }^{2}$ Department of Medical Oncology, National Cancer Institute, Cairo University, Cairo, Egypt \\ ${ }^{3}$ Department of Biostatistics and Cancer Epidemiology, South Egypt Cancer Institute, Assiut University, Assiut, Egypt \\ ${ }^{4}$ Department of Computer Engineering, Faculty of Engineering, Cairo University, Giza, Egypt
}

Correspondence should be addressed to Amal S. Ibrahim; ibrahimamalsamy@gmail.com

Received 7 June 2014; Revised 1 September 2014; Accepted 7 September 2014; Published 21 September 2014

Academic Editor: Lance A. Liotta

Copyright (C) 2014 Amal S. Ibrahim et al. This is an open access article distributed under the Creative Commons Attribution License, which permits unrestricted use, distribution, and reproduction in any medium, provided the original work is properly cited.

\begin{abstract}
Background. This paper aims to present cancer incidence rates at national and regional level of Egypt, based upon results of National Cancer Registry Program (NCRP). Methods. NCRP stratified Egypt into 3 geographical strata: lower, middle, and upper. One governorate represented each region. Abstractors collected data from medical records of cancer centers, national tertiary care institutions, Health Insurance Organization, Government-Subsidized Treatment Program, and death records. Data entry was online. Incidence rates were calculated at a regional and a national level. Future projection up to 2050 was also calculated. Results. Age-standardized incidence rates per 100,000 were 166.6 (both sexes), 175.9 (males), and 157.0 (females). Commonest sites were liver (23.8\%), breast (15.4\%), and bladder (6.9\%) (both sexes): liver (33.6\%) and bladder (10.7\%) among men, and breast (32.0\%) and liver (13.5\%) among women. By 2050, a 3-fold increase in incident cancer relative to 2013 was estimated. Conclusion. These data are the only available cancer rates at national and regional levels of Egypt. The pattern of cancer indicated the increased burden of liver cancer. Breast cancer occupied the second rank. Study of rates of individual sites of cancer might help in giving clues for preventive programs.
\end{abstract}

\section{Introduction}

Egypt was completely lacking incidence rates at national level until the results given in the current report were obtained. Available statistics were proportions derived from single or multicenter hospital registries that could not be used for calculation of incidence rates [1-7]. The only published incidence rates are those from a cancer registry in one district in Nile delta (Gharbiah governorate). The last internal reports of this registry are for $2002[8,9]$. Incidence rates up to 2007 were published in Volumes IX and X of Cancer Incidence in Five Continents [10, 11], date of end of registry activities due to failure of sustainability. The published crude and age-standardized incidence rates from that registry are 96.5 and 132.6/100,000 males and 97.3 and 122.1/100,000 females. The commonest sites of cancer in males are liver (18.7\%), bladder (12.7\%), non-Hodgkin's lymphoma (11.0\%) and trachea, bronchus, and lung (8.2\%). The 4 sites represent $50.6 \%$ of all cancer in males. The commonest sites in females are breast (38.8\%), non-Hodgkin's lymphoma (8.5\%), liver (4.6\%), and ovary (4.5\%); all together represent $56.4 \%$ of cancer in females. There is no mention of rates of both sexes together. Studies are published using these Gharbiah data up to 2007 and are limited to specific sites of cancer mainly breast [12-15], gastrointestinal [16-18], hematopoietic [19], bladder [20], and gynecological cancers [21]. None of these geographically-limited studies and published rates could be considered as representative of Egypt, being based on results of one registry in a single delta governorate and do not have 


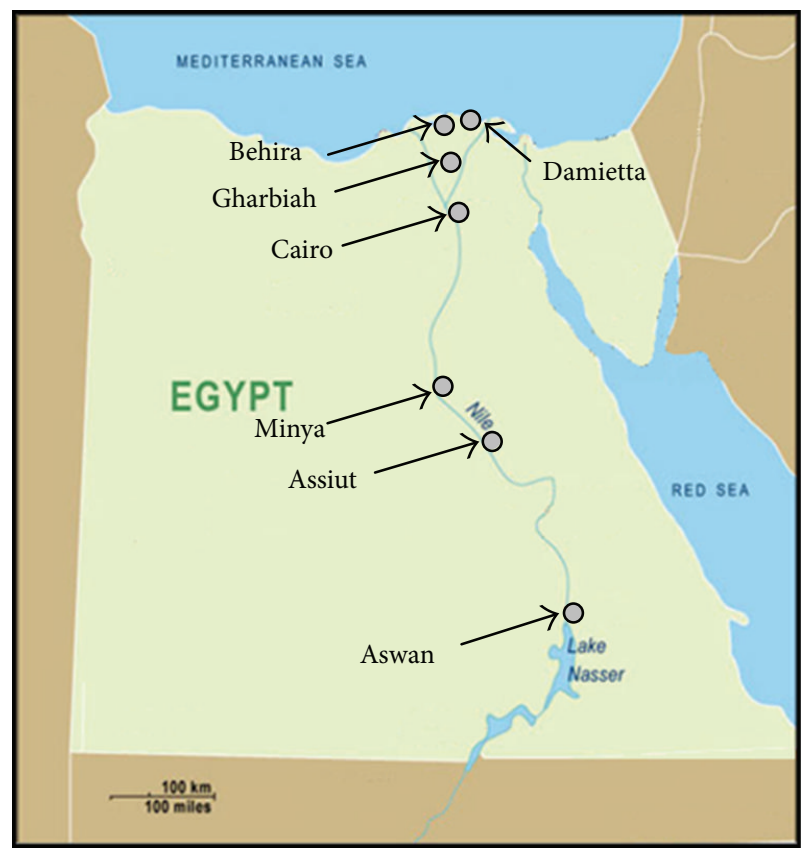

FIGURE 1: Map of Egypt showing the location of the 5 peripheral registries of the national network of population-based cancer registries National Cancer Institute, Cairo, and South Egypt Cancer Institute, Assiut.

an impact on understanding the current situation of cancer at the national level.

The National Cancer Registry Program (NCRP) was established in 2008 and became the only source for cancer incidence in the country [22]. The main objective of the current publication is to present the incidence rates of cancer in Egypt in 2008-2011 based upon data of the National Cancer Registry Program of Egypt with estimated incidence of the disease up to 2050.

\section{Materials and Methods}

For registration purposes, Egypt was stratified into 3 geographical strata (regions), namely, Lower Egypt (north of Cairo), Middle Egypt (south of Cairo), and Upper Egypt (further south, reaching the southern frontier of the country). The current report covered three districts (governorate), each representing one of the 3 regions, namely, Damietta (Nile delta), Minya (Middle Egypt), and Aswan (Upper Egypt) (Figure 1). A population-based registry was established in each of the 3 governorates, located in the Ministry of Health Cancer Center.

Trained medical doctors in the 3 registries abstracted records from their cancer centers and regularly visited establishments that dealt with cancer within the governorate for active data collection from medical records. Other sources of data were major tertiary centers on the national level as the National Cancer Institute of Cairo University, Pediatric Oncology Hospital in Cairo, and South Egypt Cancer Institute of Assiut University. Data managers in these institutions reported incident cancer cases among residents of

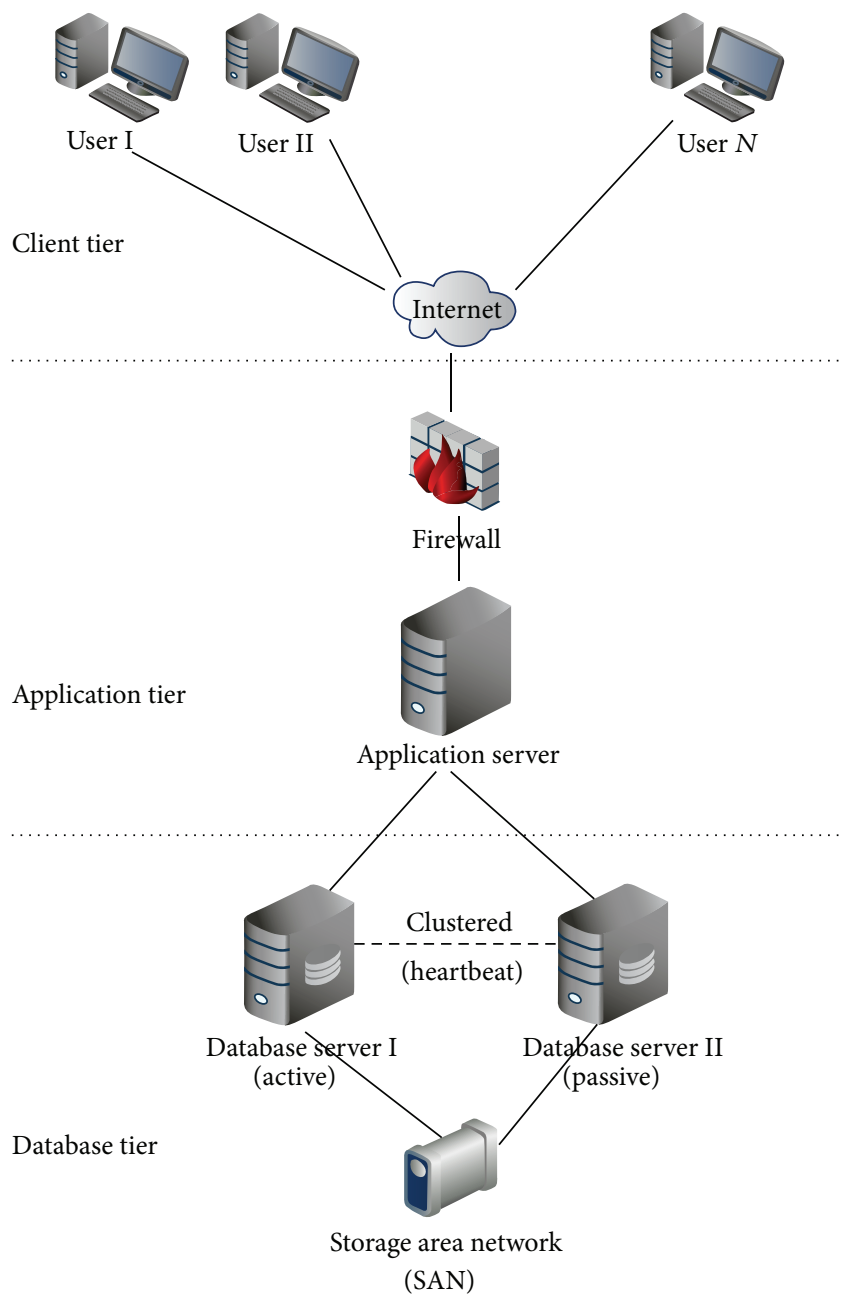

Figure 2: The NCRP Web Based System (3-Tier Architecture).

the 3 governorates that were diagnosed/treated in these institutions. Health Insurance Organization and the GovernmentSubsidized Treatment Program periodically supplied their data. Death registers in local health directorates were regularly checked for cancer deaths from the 3 governorates.

A web-based software was developed for online data entry, validity checks, and data analysis. The database was centralized in the Ministry of Communication and Information Technology server (Figure 2) with backups in the Ministry of Health and the National Cancer Institute. Computer checks were achieved using DEPedits Conversion and Check Programs for Cancer Registries software [23]. Duplicates were eliminated using the National Identification Number and a clean database was achieved ready for analysis. Registration covered all invasive cancers (behavior code/3), in situ breast cancer (topography code C50.- and behavior code/2), in situ urinary bladder cancer (topography code C67.- and behavior code/2), and borderline tumors of the brain (topography code C71.- and behavior code/1) [24].

For the current report, we used data from Aswan (2008), Minya (2009), and Damietta (2009-2011) to represent the 3 geographical strata of Egypt (Table 1). Crude, age-specific, and world population age-standardized incidence rates were 
TABLE 1: Population parameters of the 3 regions of Egypt and corresponding registries used in the current report to calculate regional and national incidence rates.

\begin{tabular}{lccc}
\hline Region characteristics & Upper Egypt & Middle Egypt & Lower Egypt \\
\hline Regional Registry & Aswan & Minia & Damietta \\
Registration period & 2008 & 2009 & $2009-2011$ \\
Registry Population & $1,074,131$ & $4,426,528$ & $3,586,056^{* *}$ \\
Region population $^{*}$ & $4,645,449$ & $16,161,200$ & $30,342,291$ \\
\hline
\end{tabular}

${ }^{*}$ Based upon 2006 census.

${ }^{* *}$ Person years during the registration period.

TABLE 2: Incidence rates of Cancer in Egypt (/100,000 populations) classified by region and sex for all cancer sites with and without nonmelanoma skin cancer (C44).

\begin{tabular}{|c|c|c|c|c|c|c|c|c|}
\hline & \multicolumn{2}{|c|}{ Males } & \multicolumn{2}{|c|}{ Females } & \multicolumn{2}{|c|}{ All } & \multicolumn{2}{|c|}{ Male : female ratio } \\
\hline & $\begin{array}{l}\text { Crude rate } \\
(95 \% \mathrm{CI})\end{array}$ & $\begin{array}{c}\text { ASR } \\
(95 \% \mathrm{CI})\end{array}$ & $\begin{array}{l}\text { Crude rate } \\
(95 \% \mathrm{CI})\end{array}$ & $\begin{array}{c}\text { ASR } \\
(95 \% \mathrm{CI}) \\
\end{array}$ & $\begin{array}{l}\text { Crude rate } \\
(95 \% \mathrm{CI})\end{array}$ & $\begin{array}{c}\text { ASR } \\
(95 \% \mathrm{CI})\end{array}$ & Crude rate & ASR \\
\hline \multicolumn{9}{|l|}{ All sites } \\
\hline (i) Upper Egypt & $\begin{array}{c}97.1 \\
(89.1-105.8)\end{array}$ & $\begin{array}{c}142.8 \\
(133.1-153.2)\end{array}$ & $\begin{array}{c}116.9 \\
(108.1-126.5)\end{array}$ & $\begin{array}{c}167.1 \\
(156.5-178.4)\end{array}$ & $\begin{array}{c}107.0 \\
(101.0-113.3)\end{array}$ & $\begin{array}{c}155.0 \\
(147.7-162.6)\end{array}$ & $0.8: 1$ & $0.9: 1$ \\
\hline (ii) Middle Egypt & $\begin{array}{c}109.7 \\
(105.4-114.1)\end{array}$ & $\begin{array}{c}170.0 \\
(164.7-175.5)\end{array}$ & $\begin{array}{c}95.9 \\
(91.1-100.2)\end{array}$ & $\begin{array}{c}132.1 \\
(127.4-137.0)\end{array}$ & $\begin{array}{c}102.9 \\
(100.0-106.0)\end{array}$ & $\begin{array}{c}151.1 \\
(147.5-154.8)\end{array}$ & $1.1: 1$ & $1.3: 1$ \\
\hline (iii) Lower Egypt & $\begin{array}{c}138.5 \\
(133.2-144.0)\end{array}$ & $\begin{array}{c}191.8 \\
(185.6-198.2)\end{array}$ & $\begin{array}{c}131.7 \\
(126.5-137.2)\end{array}$ & $\begin{array}{c}173.3 \\
(167.3-179.6)\end{array}$ & $\begin{array}{c}135.2 \\
(131.4-139.1)\end{array}$ & $\begin{array}{c}182.6 \\
(178.2-187.1)\end{array}$ & $1.1: 1$ & $1.1: 1$ \\
\hline $\begin{array}{l}\text { (iv) Calculated rates of } \\
\text { Egypt }\end{array}$ & $\begin{array}{c}117.3 \\
(116.0-118.6)\end{array}$ & $\begin{array}{c}178.5 \\
(176.9-180.2)\end{array}$ & $\begin{array}{c}111.7 \\
(110.4-113.0)\end{array}$ & $\begin{array}{c}159.1 \\
(157.6-160.7)\end{array}$ & $\begin{array}{c}114.5 \\
(113.6-115.5)\end{array}$ & $\begin{array}{c}169.0 \\
(167.9-170.2)\end{array}$ & $1.1: 1$ & $1.1: 1$ \\
\hline \multicolumn{9}{|c|}{$\begin{array}{l}\text { All sites (excluding } \\
\text { nonmelanoma skin cancer } \\
\text { C44) }\end{array}$} \\
\hline (i) Upper Egypt & $\begin{array}{c}96.0 \\
(88.1-1104.6)\end{array}$ & $\begin{array}{c}141.0 \\
(131.4-151.4)\end{array}$ & $\begin{array}{c}115.1 \\
(106.3-124.5)\end{array}$ & $\begin{array}{c}163.9 \\
(153.4-175.1)\end{array}$ & $\begin{array}{c}105.5 \\
(99.5-111.8)\end{array}$ & $\begin{array}{c}152.5 \\
(145.5-160.1)\end{array}$ & $0.8: 1$ & $0.9: 1$ \\
\hline (ii) Middle Egypt & $\begin{array}{c}108.0 \\
(103.8-112.3)\end{array}$ & $\begin{array}{c}167.2 \\
(162.0-172.6)\end{array}$ & $\begin{array}{c}94.9 \\
(90.9-99.1)\end{array}$ & $\begin{array}{c}130.7 \\
(126.0-135.6)\end{array}$ & $\begin{array}{c}101.6 \\
98.7-104.6)\end{array}$ & $\begin{array}{c}149.0 \\
(145.5-152.6)\end{array}$ & $1.1: 1$ & $1.3: 1$ \\
\hline (iii) Lower Egypt & $\begin{array}{c}136.7 \\
(131.5-142.2)\end{array}$ & $\begin{array}{c}189.1 \\
(182.9-195.5)\end{array}$ & $\begin{array}{c}130.1 \\
(124.8-135.5)\end{array}$ & $\begin{array}{c}170.9 \\
(164.9-177.1)\end{array}$ & $\begin{array}{c}133.5 \\
(129.7-137.3)\end{array}$ & $\begin{array}{c}180.0 \\
(175.7-184.4)\end{array}$ & $1.1: 1$ & $1.1: 1$ \\
\hline $\begin{array}{l}\text { (iv) Calculated rates of } \\
\text { Egypt }\end{array}$ & $\begin{array}{c}115.7 \\
(114.4-117.0)\end{array}$ & $\begin{array}{c}175.9 \\
(174.3-177.5)\end{array}$ & $\begin{array}{c}110.3 \\
(109.0-111.6)\end{array}$ & $\begin{array}{c}157.0 \\
(155.4-158.5)\end{array}$ & $\begin{array}{c}113.1 \\
(112.2-114.0)\end{array}$ & $\begin{array}{c}166.6 \\
(165.5-167.8)\end{array}$ & $1: 1$ & $1.1: 1$ \\
\hline
\end{tabular}

calculated and expressed/100,000 population. Statistics were published at the level of the 3-character ICD-10 codes [10]. The format of IARC publication: "Cancer Incidence in Five Continents, Vol. X" [11], was used for grouping of ICD codes. Statistics for all sites of cancer were expressed twice, with and without nonmelanoma skin cancer (C44). Confidence intervals were calculated following SEER methodology [25].

We developed a model to use incidence data of the population-based registries of the 3 regions (Lower, Middle, and Upper Egypt) to get incidence rates for the entire country. The first step was to apply the age-specific incidence rates of each registry to the population of the stratum it represented to get the number per gender of incident cases in different age groups and for all ages together in this region using data of Egypt last census [26]. Then, we used these statistics to estimate the crude and age specific incidence rates (ASIR) of cancer in the 3 regions together, considered to be representative of the entire country. These rates were applied to the total population of Egypt to get number of incident cancers and crude rate and ASR (world) at national. This procedure was applied for each cancer site and for all sites together per gender. For projections up to 2050, the ASIRs were applied to the projected population of the corresponding year to get the number of patients/age group. Crude and ASR (world) could then be obtained. Steps of calculations are detailed in the Appendix.

\section{Results}

3.1. National Incidence Rates and Proportions. The crude incidence rates on the national level for all sites excluding nonmelanoma skin cancer (C44) were 113.1/100,000 (both sexes), 115.7/100,000 (males), and 110.3/100,000 (females). The age-standardized rates (world) were 166.6/100,000 (both sexes), 175.9/100,000 (males), and 157.0/100,000 (females) as shown in Table 2. Proportions, crude, age standardized incidence rates and detailed age-specific rates of cancer sites according to ICD-10 format are shown in Tables 3 and 4 for 


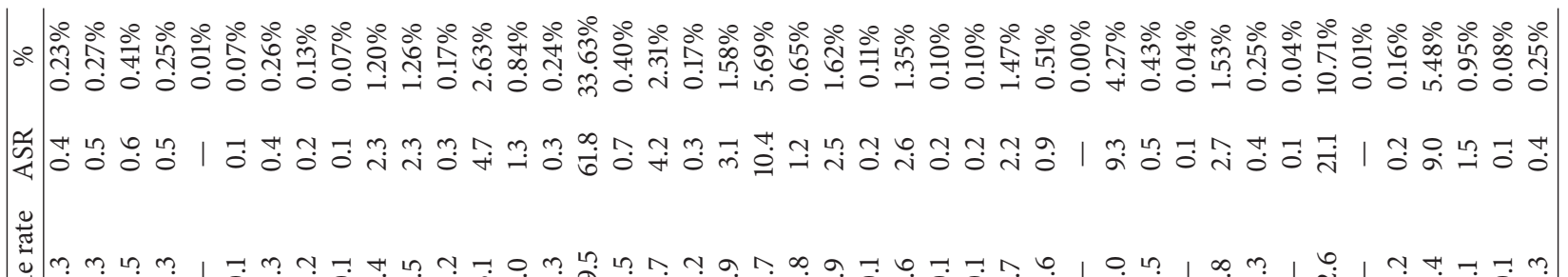

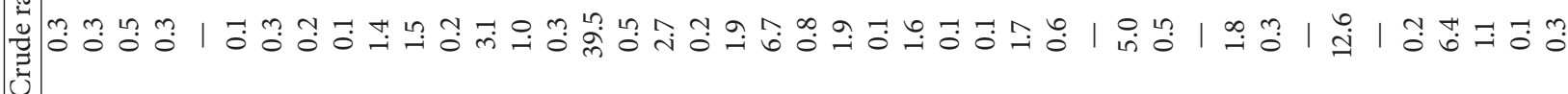

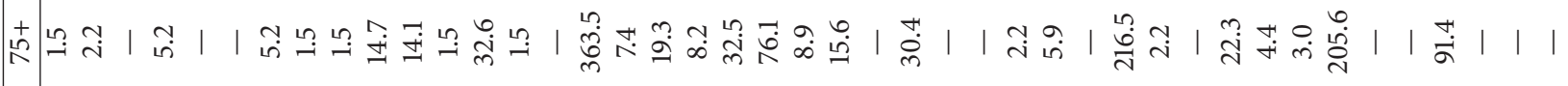

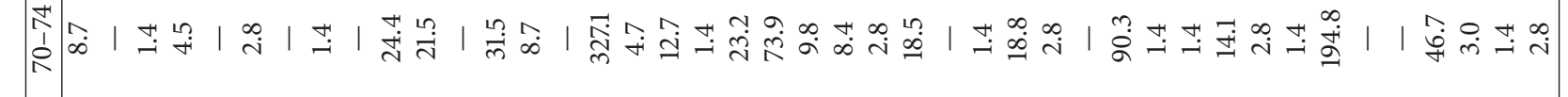

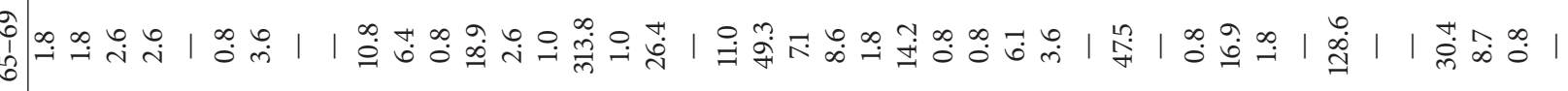

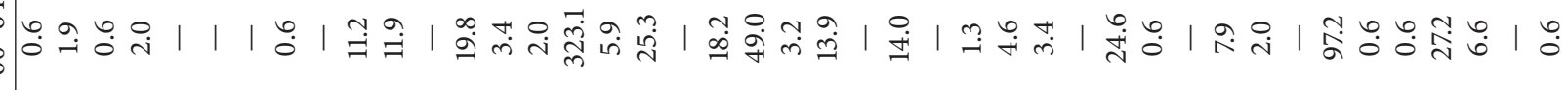

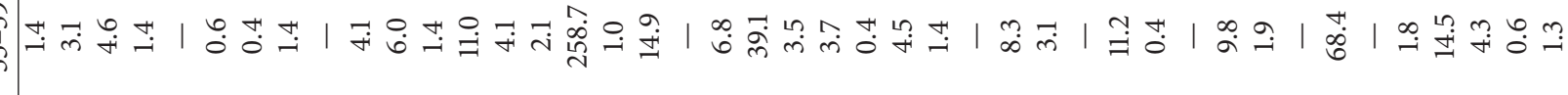

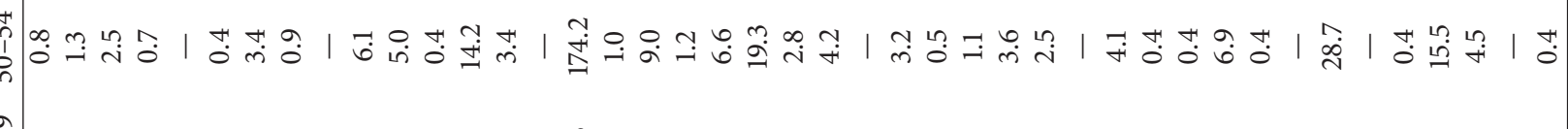

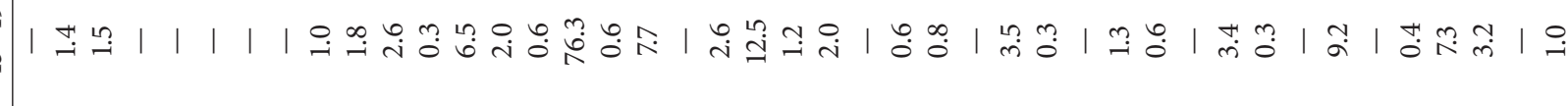

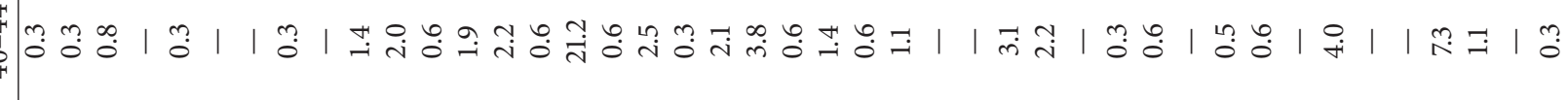

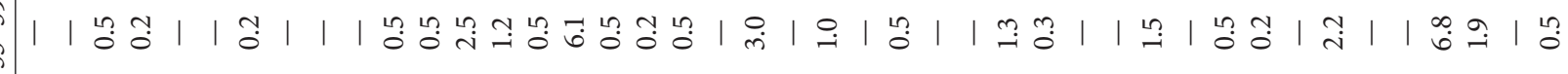

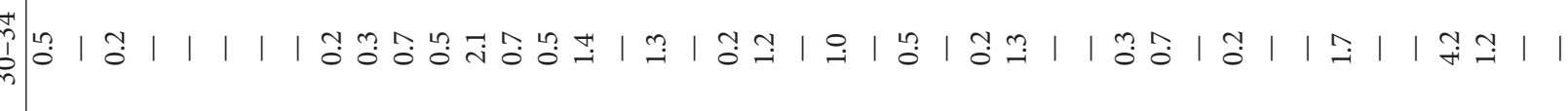

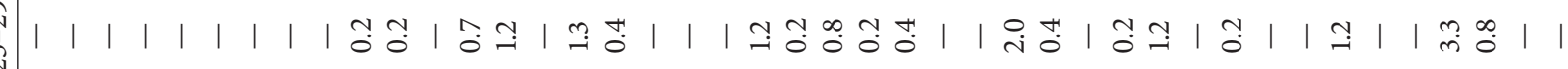

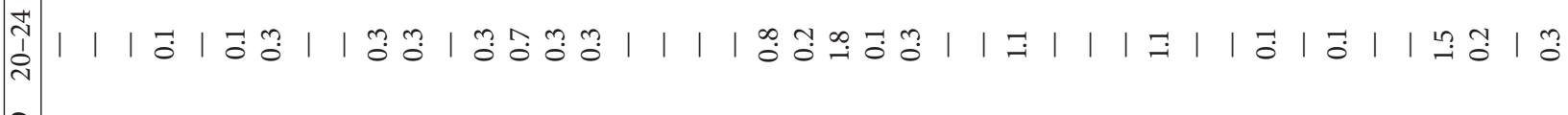

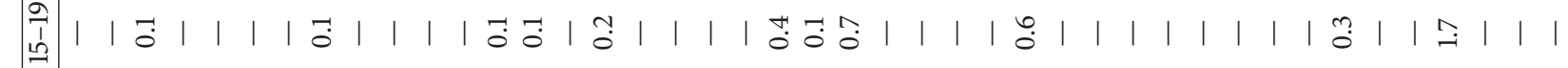
尊

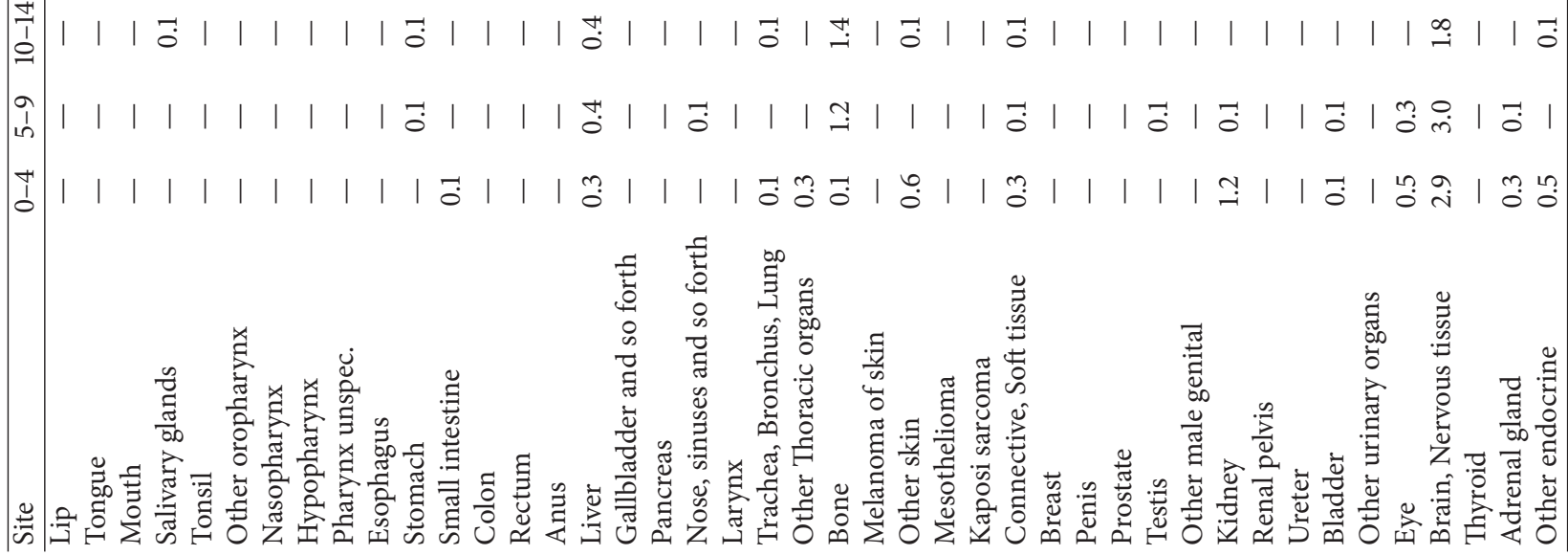




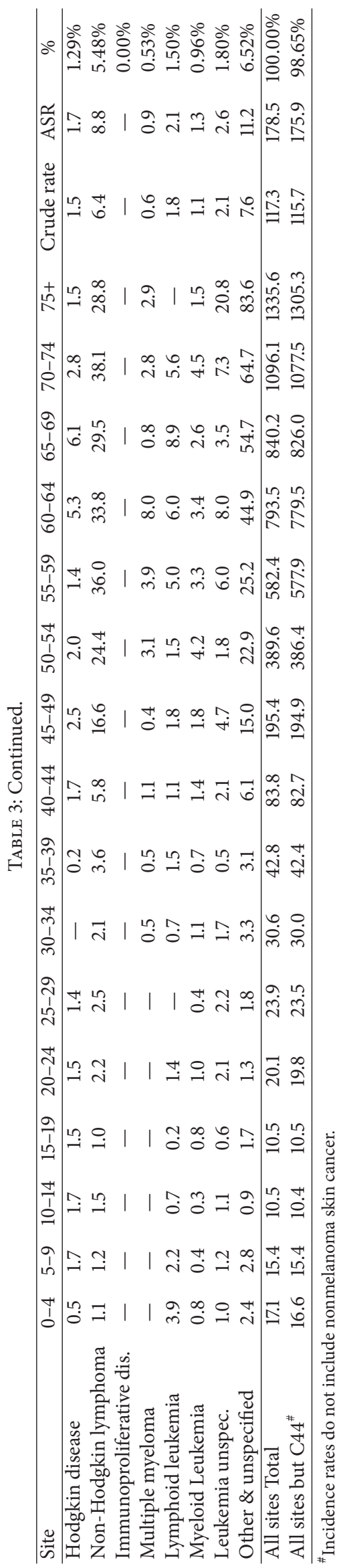




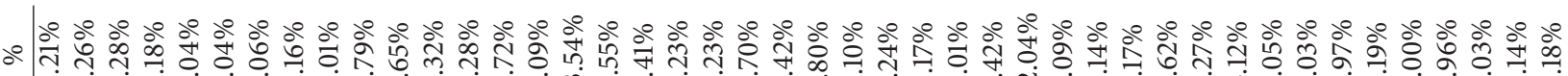
年

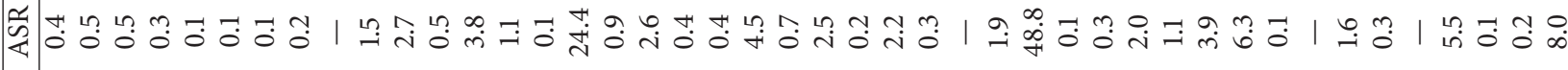

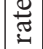

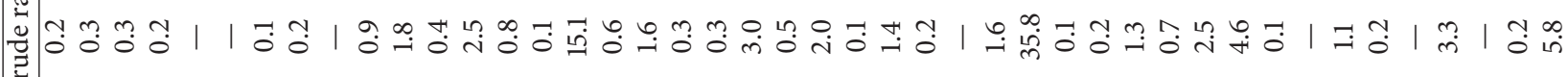
ठै

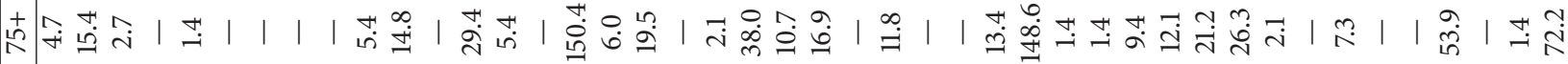

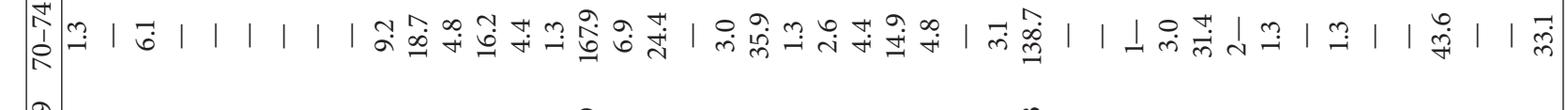

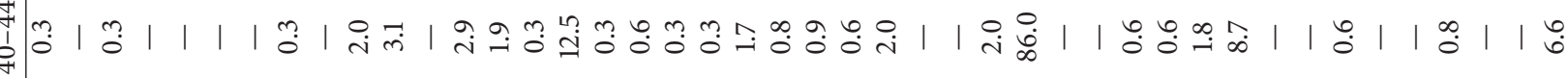

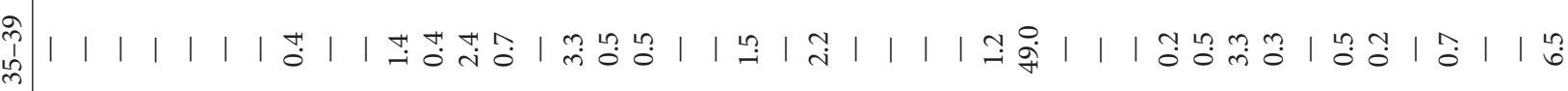

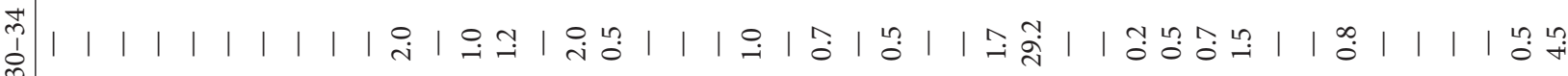

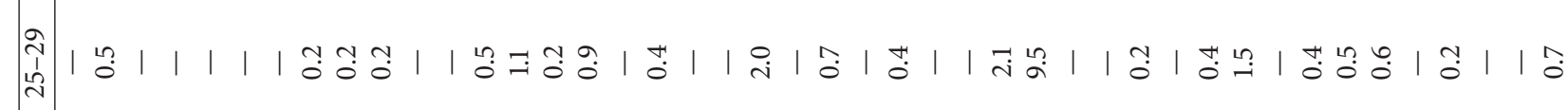

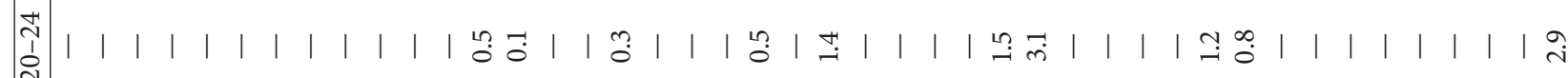

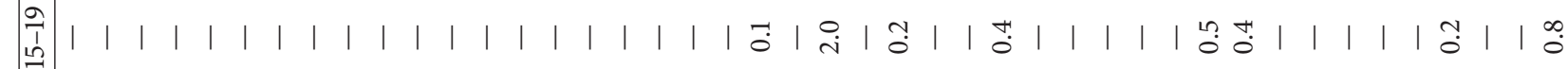
矛| |

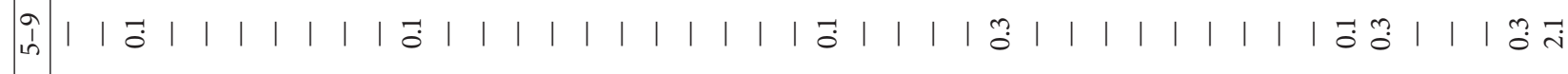
苟| | | | | | |

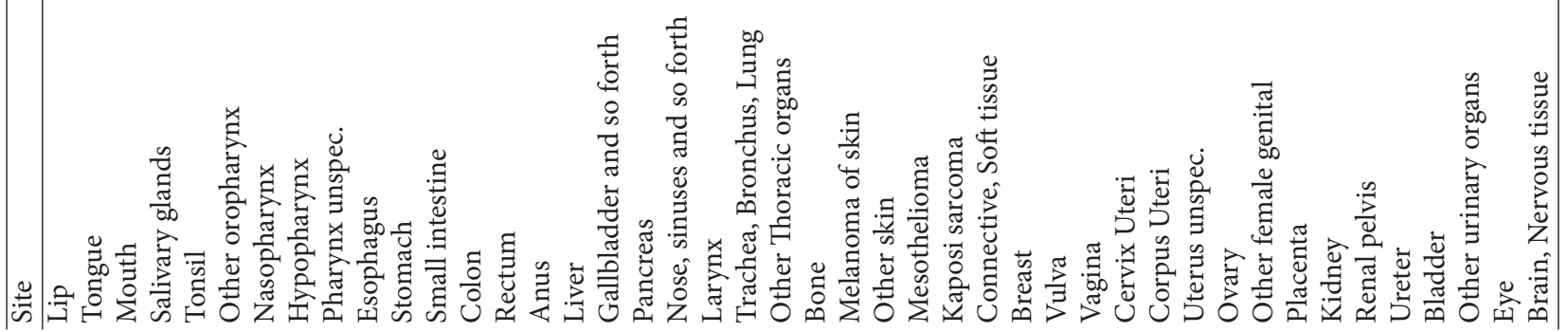




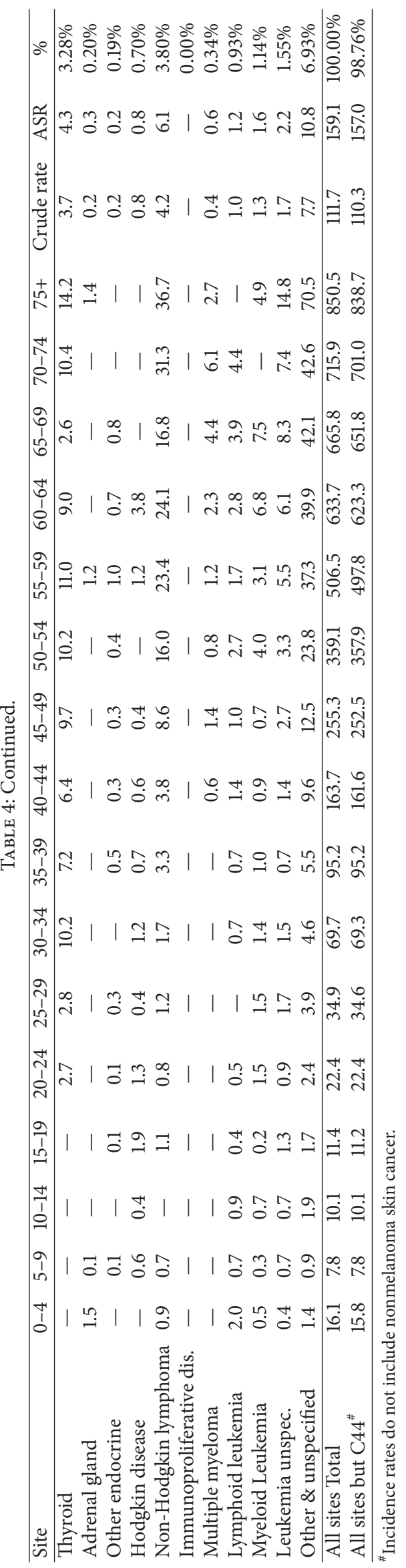




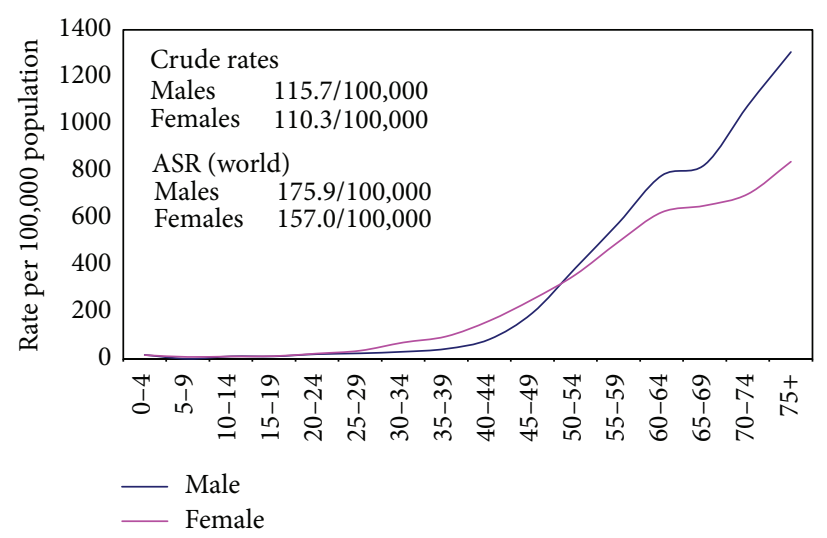

Number of incidence rates do not include nonmelanoma skin cancer

FIGURE 3: Calculated age specific incidence rates for Egypt 20082011.

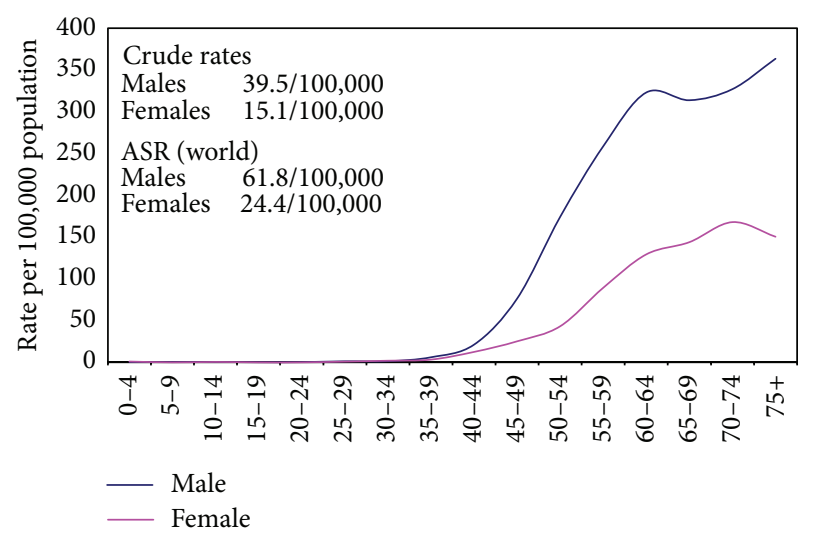

FIGURE 4: Calculated age specific incidence rates for liver cancer in Egypt 2008-2011.

individual sites of cancer and for all sites together by gender. The age-specific rates are represented graphically in Figure 3 for all cancers and Figures 4, 5, and 6 for breast, liver, and bladder cancer as examples of some of the more frequent cancer sites.

Table 5 depicts the proportions and rates of the most frequent cancer sites by gender. There was predominance of liver, breast, and bladder cancer that represented approximately $46 \%$ of all cancers. Liver and bladder cancers represented approximately $44 \%$ of cancer in males. In females, breast and liver cancer occupied the top ranks accounting for around $45 \%$ of all cancers.

3.2. Frequencies and Incidence Rates/Geographical Strata. The frequencies of individual sites of cancer and their incidence rates by geographical stratum and sex are detailed in Tables 6 and 7. Table 8 depicts the most common sites of cancer that accounted for approximately $3 / 4$ of cases. For the 2 sexes together, the top 2 ranks in the 3 regions were liver and breast cancer. The proportions and ASR of liver cancer were highest in Lower Egypt (29.6\% and 56.8/100,000), less in Middle, and least in Upper Egypt (8.2\% and 13.1/100,000).

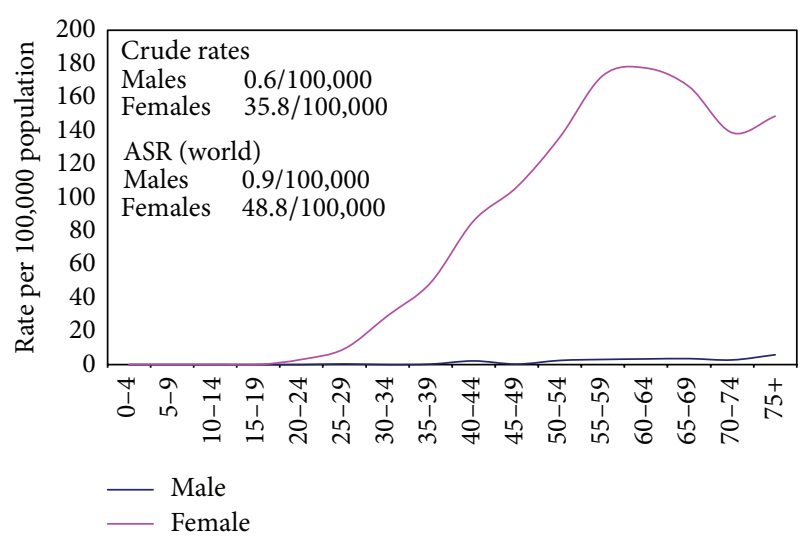

FIGURE 5: Calculated age specific incidence rates for breast cancer in Egypt 2008-2011.

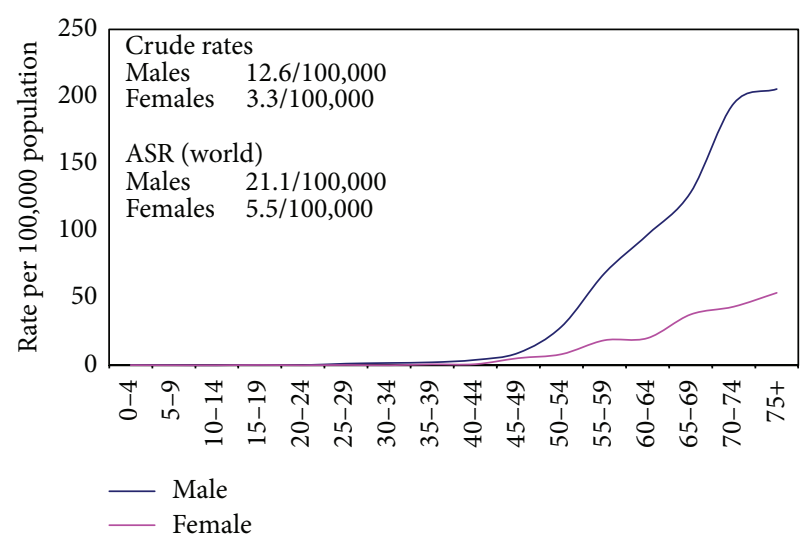

FIGURE 6: Calculated age specific incidence rates for urinary bladder cancer in Egypt 2008-2011.

Among males in the 3 regions, liver and bladder cancer occupied the top 2 ranks. The proportion and ASR of liver cancer were highest in Lower Egypt (41.7\% and 81.0/100,000) and lowest in Upper Egypt (11.8\% and 17.5/100,000). Cancer of the lung occupied the third or fourth ranks representing $5-7 \%$ of cancers and Non-Hodgkin lymphoma was among the 5 most common cancers in Lower Egypt only having a proportion of $6.0 \%$ and ASR $10.3 / 100,000$.

Among females, the pattern in the 3 regions was dominated by the high frequency of breast cancer and liver cancer. Proportion of liver cancer was highest in Lower Egypt (16.4\%), less in Middle Egypt, and lowest in Upper Egypt (8.9\% and $5.1 \%$ resp.).

3.3. Estimated Number of Incident Cancer Cases 20132050. During the period 2013-2050, population of Egypt is expected to increase to approximately $160 \%$ the 2013 population size. Applying the current age-specific incidence rates to successive populations would lead to a progressive increase in number of incident cases from 114,985 in 2013 to 331,169 in 2050, approximately $290 \%$ of 2013 incidence (Table 9 and Figure 7). This increase reflected both population growth and demographic change mainly due to ageing of population. 
TABle 5: The most frequent cancers in Egypt estimated using the results of the National Population-Based Registry Program of Egypt 20082011.

\begin{tabular}{|c|c|c|c|c|}
\hline & Site & $\%$ & Crude rate & ASR \\
\hline \multirow{6}{*}{ Males } & Liver & 33.63 & 39.5 & 61.8 \\
\hline & Bladder & 10.71 & 12.6 & 21.1 \\
\hline & Lung $^{\#}$ & 5.69 & 6.7 & 10.4 \\
\hline & Non-Hodgkin lymphoma & 5.48 & 6.4 & 8.8 \\
\hline & Brain $^{\# \#}$ & 5.48 & 6.4 & 8.8 \\
\hline & Prostate & 4.27 & 5.0 & 9.3 \\
\hline \multirow{6}{*}{ Females } & Breast & 32.04 & 35.8 & 48.8 \\
\hline & Liver & 13.54 & 15.1 & 24.4 \\
\hline & Brain $^{\# \#}$ & 5.18 & 5.8 & 8.0 \\
\hline & Ovary & 4.12 & 4.6 & 6.3 \\
\hline & Non-Hodgkin lymphoma & 3.80 & 4.2 & 6.1 \\
\hline & Thyroid & 3.28 & 3.7 & 4.3 \\
\hline \multirow{6}{*}{ Both Sexes } & Liver & 23.81 & 27.5 & 43.6 \\
\hline & Breast & 15.41 & 17.8 & 24.3 \\
\hline & Bladder & 6.94 & 8.0 & 13.5 \\
\hline & Brain $^{\#}$ & 5.29 & 6.1 & 8.5 \\
\hline & Non-Hodgkin lymphoma & 4.64 & 5.4 & 7.5 \\
\hline & Lung $^{\#}$ & 4.22 & 4.9 & 7.5 \\
\hline
\end{tabular}

\#Includes trachea, bronchus, and lung tumors.

\#\# Includes brain and nervous system tumors.

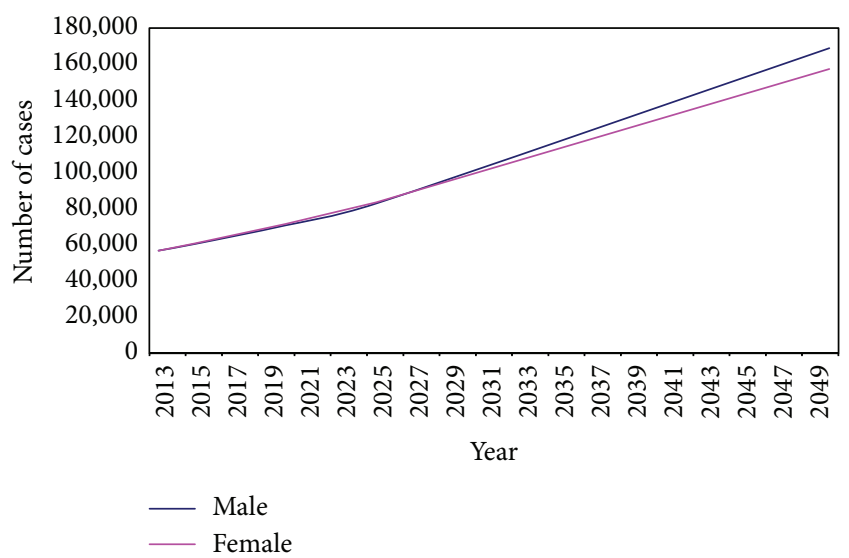

FIGURE 7: Estimated number of cases in Egypt (2013-2050).

Population growth alone would increase the number of incident cases by $55.2 \%$ in 2015 . This fraction progressively decreased to become $32.8 \%$ in 2050 . The fraction due to ageing gradually increased to reach $67.2 \%$ in 2050 (Figure 8).

\section{Discussion}

When the National Cancer Registry Program of Egypt was designed, there had been a number of challenges that were addressed. One of the most important challenges was design of a sample that could be representative of such a big country. Other challenges included complete capture of incident cancer cases among residents of selected governorates and best guarantee of quality of data and sustainability of the

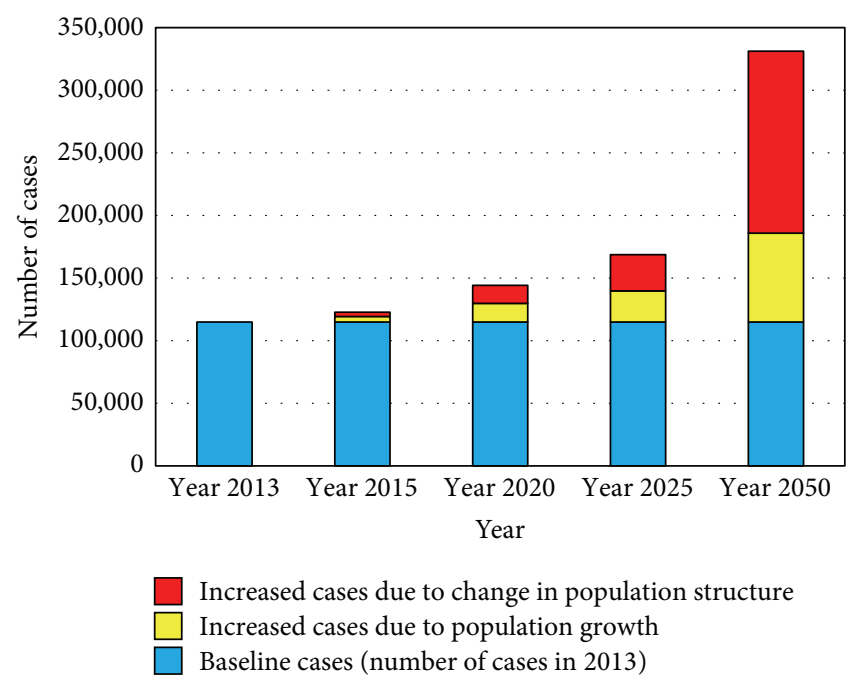

FIGURE 8: Estimated number of cases in Egypt (2013-2050) and causes of the increase in cases.

program to avoid going through survey-like data collection that need to be repeated, a methodology that proved to be inappropriate [27].

Dealing with population-based registration, the word national might be confusing. Actually, and with the exception of very few examples mainly old registries like that of Denmark and registries in small countries like Singapore, complete national coverage is not accomplished $[27,28]$. The US is an example of a huge country with 18 population-based registries spread over the states without a central national 
TABLE 6: Incidence rates/100,000 population of individual cancer sites in Lower, Middle, and Upper Egypt: males.

\begin{tabular}{|c|c|c|c|c|c|c|c|c|c|}
\hline \multirow{3}{*}{ Primary site } & \multicolumn{3}{|c|}{ Lower Egypt } & \multicolumn{3}{|c|}{ Middle Egypt } & \multicolumn{3}{|c|}{ Upper Egypt } \\
\hline & \multicolumn{3}{|c|}{ 2009-2011 } & \multicolumn{3}{|c|}{2009} & \multicolumn{3}{|c|}{2008} \\
\hline & Crude & ASR & $\%$ & Crude & ASR & $\%$ & Crude & ASR & $\%$ \\
\hline Lip & 0.4 & 0.4 & $0.28 \%$ & 0.3 & 0.5 & $0.24 \%$ & 0.4 & 0.6 & $0.38 \%$ \\
\hline Tongue & 0.3 & 0.3 & $0.20 \%$ & 0.2 & 0.4 & $0.20 \%$ & 1.1 & 1.5 & $1.15 \%$ \\
\hline Mouth & 0.2 & 0.3 & $0.16 \%$ & 0.8 & 1.1 & $0.73 \%$ & 1.3 & 1.9 & $1.34 \%$ \\
\hline Salivary glands & 0.3 & 0.4 & $0.20 \%$ & 0.4 & 0.5 & $0.36 \%$ & 0.6 & 0.9 & $0.57 \%$ \\
\hline Tonsil & 0.0 & 0.0 & $0.00 \%$ & 0.0 & 0.1 & $0.04 \%$ & 0.0 & 0.0 & $0.00 \%$ \\
\hline Other oropharynx & 0.0 & 0.0 & $0.00 \%$ & 0.2 & 0.3 & $0.20 \%$ & 0.2 & 0.3 & $0.19 \%$ \\
\hline Nasopharynx & 0.5 & 0.5 & $0.35 \%$ & 0.1 & 0.1 & $0.12 \%$ & 0.6 & 1.0 & $0.57 \%$ \\
\hline Hypopharynx & 0.0 & 0.0 & $0.00 \%$ & 0.3 & 0.5 & $0.28 \%$ & 0.6 & 0.9 & $0.57 \%$ \\
\hline Pharynx unspec. & 0.1 & 0.1 & $0.04 \%$ & 0.1 & 0.1 & $0.08 \%$ & 0.2 & 0.3 & $0.19 \%$ \\
\hline Esophagus & 1.0 & 1.3 & $0.71 \%$ & 1.8 & 3.0 & $1.61 \%$ & 3.9 & 5.5 & $4.01 \%$ \\
\hline Stomach & 1.4 & 2.0 & $0.98 \%$ & 1.7 & 2.5 & $1.53 \%$ & 2.4 & 3.8 & $2.48 \%$ \\
\hline Small intestine & 0.1 & 0.1 & $0.04 \%$ & 0.5 & 0.6 & $0.44 \%$ & 0.2 & 0.2 & $0.19 \%$ \\
\hline Colon & 4.0 & 5.4 & $2.91 \%$ & 2.3 & 3.7 & $2.10 \%$ & 2.4 & 3.7 & $2.48 \%$ \\
\hline Rectum & 0.9 & 1.1 & $0.67 \%$ & 1.2 & 1.6 & $1.13 \%$ & 0.7 & 1.1 & $0.76 \%$ \\
\hline Anus & 0.4 & 0.4 & $0.28 \%$ & 0.2 & 0.2 & $0.16 \%$ & 0.4 & 0.5 & $0.38 \%$ \\
\hline Liver & 57.8 & 81 & $41.71 \%$ & 22.4 & 37.6 & $20.42 \%$ & 11.5 & 17.5 & $11.83 \%$ \\
\hline Gallbladder and so forth & 0.5 & 0.5 & $0.39 \%$ & 0.4 & 0.7 & $0.32 \%$ & 1.3 & 2.2 & $1.34 \%$ \\
\hline Pancreas & 3.2 & 4.4 & $2.28 \%$ & 2.1 & 3.5 & $1.94 \%$ & 3.5 & 5.4 & $3.63 \%$ \\
\hline Nose, sinuses and so forth & 0.1 & 0.1 & $0.04 \%$ & 0.4 & 0.6 & $0.32 \%$ & 0.6 & 0.9 & $0.57 \%$ \\
\hline Larynx & 0.8 & 1.3 & $0.59 \%$ & 3.3 & 5.7 & $3.03 \%$ & 3.9 & 6.0 & $4.01 \%$ \\
\hline Trachea, Bronchus, Lung & 7.6 & 10.1 & $5.47 \%$ & 6.3 & 10.8 & $5.77 \%$ & 7.4 & 11.5 & $7.63 \%$ \\
\hline Other Thoracic organs & 1.0 & 1.3 & $0.71 \%$ & 0.8 & 1.2 & $0.69 \%$ & 0.6 & 0.8 & $0.57 \%$ \\
\hline Bone & 1.9 & 2.4 & $1.34 \%$ & 2.3 & 3.4 & $2.10 \%$ & 1.5 & 1.9 & $1.53 \%$ \\
\hline Melanoma of skin & 0.2 & 0.2 & $0.12 \%$ & 0.1 & 0.1 & $0.12 \%$ & 0.0 & 0.0 & $0.00 \%$ \\
\hline Other skin & 1.8 & 2.7 & $1.30 \%$ & 1.7 & 2.8 & $1.53 \%$ & 1.1 & 1.8 & $1.15 \%$ \\
\hline Mesothelioma & 0.0 & 0.0 & $0.00 \%$ & 0.3 & 0.4 & $0.24 \%$ & 0.4 & 0.6 & $0.38 \%$ \\
\hline Kaposi sarcoma & 0.1 & 0.1 & $0.08 \%$ & 0.2 & 0.3 & $0.16 \%$ & 0.0 & 0.0 & $0.00 \%$ \\
\hline Connective, Soft tissue & 2.5 & 2.6 & $1.77 \%$ & 0.5 & 0.8 & $0.48 \%$ & 3.0 & 3.8 & $3.05 \%$ \\
\hline Breast & 0.7 & 0.8 & $0.47 \%$ & 0.4 & 0.6 & $0.32 \%$ & 1.1 & 1.8 & $1.15 \%$ \\
\hline Penis & 0.0 & 0.0 & $0.00 \%$ & 0.0 & 0.0 & $0.00 \%$ & 0.0 & 0.0 & $0.00 \%$ \\
\hline Prostate & 6.7 & 11.7 & $4.84 \%$ & 2.9 & 5.2 & $2.66 \%$ & 5.7 & 9.2 & $5.92 \%$ \\
\hline Testis & 0.5 & 0.4 & $0.35 \%$ & 0.5 & 0.7 & $0.48 \%$ & 0.4 & 0.5 & $0.38 \%$ \\
\hline Other male genital & 0.0 & 0.0 & $0.00 \%$ & 0.1 & 0.2 & $0.12 \%$ & 0.0 & 0.0 & $0.00 \%$ \\
\hline Kidney & 2.2 & 3.2 & $1.61 \%$ & 1.7 & 2.5 & $1.53 \%$ & 0.9 & 1.3 & $0.95 \%$ \\
\hline Renal pelvis & 0.2 & 0.3 & $0.12 \%$ & 0.5 & 0.8 & $0.48 \%$ & 0.4 & 0.5 & $0.38 \%$ \\
\hline Ureter & 0.1 & 0.1 & $0.04 \%$ & 0.0 & 0.1 & $0.04 \%$ & 0.0 & 0.0 & $0.00 \%$ \\
\hline Bladder & 12.2 & 19 & $8.82 \%$ & 15.6 & 26.4 & $14.25 \%$ & 12.2 & 19.3 & $12.60 \%$ \\
\hline Other urinary organs & 0.0 & 0.0 & $0.00 \%$ & 0.0 & 0.0 & $0.00 \%$ & 0.2 & 0.3 & $0.19 \%$ \\
\hline Eye & 0.1 & 0.2 & $0.08 \%$ & 0.3 & 0.4 & $0.24 \%$ & 0.7 & 0.6 & $0.76 \%$ \\
\hline Brain, Nervous tissue & 6.2 & 8.1 & $4.49 \%$ & 8.0 & 12.5 & $7.26 \%$ & 5.2 & 6.7 & $5.34 \%$ \\
\hline Thyroid & 1.3 & 1.5 & $0.91 \%$ & 1.2 & 1.7 & $1.05 \%$ & 0.7 & 1.1 & $0.76 \%$ \\
\hline Adrenal gland & 0.0 & 0.0 & $0.00 \%$ & 0.1 & 0.2 & $0.12 \%$ & 0.6 & 0.8 & $0.57 \%$ \\
\hline Other endocrine & 0.1 & 0.1 & $0.08 \%$ & 0.6 & 0.8 & $0.56 \%$ & 0.4 & 0.4 & $0.38 \%$ \\
\hline Hodgkin disease & 1.6 & 1.8 & $1.18 \%$ & 1.7 & 2.0 & $1.53 \%$ & 1.5 & 1.5 & $1.53 \%$ \\
\hline Non-Hodgkin lymphoma & 8.3 & 10.3 & $6.03 \%$ & 5.2 & 7.6 & $4.76 \%$ & 2.8 & 4.2 & $2.86 \%$ \\
\hline Immunoproliferative dis. & 0.0 & 0.0 & $0.00 \%$ & 0.0 & 0.0 & $0.00 \%$ & 0.0 & 0.0 & $0.00 \%$ \\
\hline Multiple myeloma & 0.7 & 0.9 & $0.51 \%$ & 0.7 & 1.1 & $0.61 \%$ & 0.2 & 0.3 & $0.19 \%$ \\
\hline Lymphoid leukemia & 1.7 & 2.2 & $1.22 \%$ & 1.8 & 2.3 & $1.61 \%$ & 3.0 & 3.1 & $3.05 \%$ \\
\hline
\end{tabular}


TABLE 6: Continued.

\begin{tabular}{|c|c|c|c|c|c|c|c|c|c|}
\hline \multirow{3}{*}{ Primary site } & \multirow{2}{*}{\multicolumn{3}{|c|}{$\begin{array}{l}\text { Lower Egypt } \\
\text { 2009-2011 }\end{array}$}} & \multirow{2}{*}{\multicolumn{3}{|c|}{$\begin{array}{l}\text { Middle Egypt } \\
2009\end{array}$}} & \multirow{2}{*}{\multicolumn{3}{|c|}{$\begin{array}{c}\text { Upper Egypt } \\
2008\end{array}$}} \\
\hline & & & & & & & & & \\
\hline & Crude & ASR & $\%$ & Crude & ASR & $\%$ & Crude & ASR & $\%$ \\
\hline Myeloid Leukemia & 0.9 & 1.0 & $0.63 \%$ & 1.6 & 1.8 & $1.45 \%$ & 1.9 & 2.5 & $1.91 \%$ \\
\hline Leukemia unspec. & 2.4 & 3.1 & $1.73 \%$ & 2.0 & 2.6 & $1.86 \%$ & 1.1 & 1.1 & $1.15 \%$ \\
\hline Other \& unspecified & 5.9 & 8.3 & $4.25 \%$ & 13.9 & 17.6 & $12.67 \%$ & 8.7 & 13 & $8.97 \%$ \\
\hline All sites Total & 138.5 & 191.8 & $100.00 \%$ & 109.7 & 170 & $100.00 \%$ & 97.1 & 142.8 & $100.00 \%$ \\
\hline All sites but C44 & 136.7 & 189.1 & $98.70 \%$ & 108 & 167.2 & $98.47 \%$ & 96 & 141 & $98.85 \%$ \\
\hline
\end{tabular}

\# Incidence rates do not include nonmelanoma skin cancer.

registry [29]. Recently, national incidence rates of Turkey were published based on results of 8 geographically spread peripheral registries [30].

With this in mind, Egypt was geographically stratified for registration purposes into 3 regions: Lower Egypt, to the north of Cairo, and Middle, and Upper Egypt to the south. Three governorates were selected from the 3 regions representing 20.9\% of the total population of Egypt. The greater Cairo, including the capital city, and Alexandria, the second capital (approximately 18 million population), were not included in the program due to difficulty in data collection and coverage of a population that daily migrates in and out of these 2 regions. Other regions that were not covered were frontier governorates; namely Matrooh, New Valley, Red Sea, and Sinai, together representing 3.3\% of total population [26]. This exclusion was due to logistic reasons being mainly inhabited by nomads or internal migrants working in the tourist industry.

To ensure complete coverage of incident cancer patients in the selected governorates, data were actively collected from medical records of oncology centers within the governorates and from national referral centers like National Cancer Institute in Cairo. Registration covered health-insured patients and patients treated on government-subsidized treatment program would minimize under registration considered a point of strength of the registry. Also, regular check of death registers helped to decrease the possibility of under registration. Death certificate only cases (DCO) accounted for almost $8 \%$ of cases which could be considered an acceptable level for a newly established registry [28].

One of the elements that contributed to the National Cancer Registry Program of Egypt was the use of a unique national identification number for duplicate elimination to prevent over registration, which is a serious threat to population-based registries $[7,28]$. A major concern during the development of a cancer registry especially populationbased, is its sustainability. An alternative that was applied in Europe and the US was to conduct successive cancer surveys as with the US Health Interview and Examination surveys. Evaluation of these surveys was negative and this method was not recommended [28]. The main reason for lack of sustainability is unavailability of needed funding and lack of collaboration of treating physicians [28]. From the very beginning, the national cancer registry was planned to be a national program and not a project with start and end dates. During all stages of its development it was gradually incorporated within the infrastructure of the health system to gradually become part of everyday routine work [31]. Quality of data was assured through computer validation and regular manual checks on the peripheral and central levels.

We also developed a mathematical model to apply the regional age-specific incidence rates to the corresponding population structure to get national estimates of all cancers and for individual cancer sites for any specified year. Mathematical modeling is a common practice used to estimate national rates from statistics of regional registries. Recently, a model was developed for china to get national rates based upon regional registries [32]. The advantage of our Egyptian model was use of Egyptian national population-based data without importing data of adjacent countries [33].

Nonetheless, the program has its points of weakness. The data should be carefully interpreted in view of the short initial phase of registration that would be of better accuracy on successive years [28]. Furthermore, some private patients that are not covered by the Government-Subsidized Treatment Program might escape registration. This would be assumed to be a small proportion. With the rising cost of cancer treatment, most patients would seek government financial support which is a constriction right.

The results given in the current report are the first ever published incidence rates on a national and regional level for Egypt derived from a population-based cancer registry program. These incidence rates would replace the proportions that have always been derived from hospital-based results [1-5]. The results were those of Damietta (Lower Egypt), Minya (Middle Egypt), and Aswan (Upper Egypt). Damietta was selected to represent the Nile delta instead of Gharbiah registry that stopped its activities before establishment of the NCRP and needed some time to be restructured to join the program. Results of these governorates were used to compute regional rates that were used to get a national estimate based upon age-specific incidence rates and population structure.

The estimated incidence rates showed differences between the 3 regions that were mainly in the incidence of liver and bladder cancers. Among males, the proportion of incident liver cancer was highest in Lower Egypt (41.7\%) and next in Middle Egypt (20.4\%) and lowest in Upper Egypt $(11.8 \%)$. Bladder cancer ranked next to liver cancer in Lower Egypt (8.8\%). In Middle Egypt, the proportion was 14.2\%, still lower than liver cancer. In Upper Egypt, liver cancer was still the most common cancer, with a small difference from bladder cancer (12.6\%). These differences could be attributed 
TABLE 7: Incidence rates/100,000 population of individual cancer sites in Lower, Middle, and Upper Egypt: females.

\begin{tabular}{|c|c|c|c|c|c|c|c|c|c|}
\hline \multirow{3}{*}{ Primary site } & \multicolumn{3}{|c|}{ Lower Egypt } & \multicolumn{3}{|c|}{ Middle Egypt } & \multicolumn{3}{|c|}{ Upper Egypt } \\
\hline & \multicolumn{3}{|c|}{ 2009-2011 } & \multicolumn{3}{|c|}{2009} & \multicolumn{3}{|c|}{2008} \\
\hline & Crude & ASR & $\%$ & Crude & ASR & $\%$ & Crude & ASR & $\%$ \\
\hline Lip & 0.3 & 0.4 & $0.26 \%$ & 0.2 & 0.4 & $0.24 \%$ & 0.0 & 0.0 & $0.00 \%$ \\
\hline Tongue & 0.3 & 0.5 & $0.26 \%$ & 0.3 & 0.5 & $0.34 \%$ & 0.2 & 0.2 & $0.16 \%$ \\
\hline Mouth & 0.1 & 0.2 & $0.09 \%$ & 0.5 & 0.8 & $0.53 \%$ & 0.9 & 1.5 & $0.80 \%$ \\
\hline Salivary glands & 0.2 & 0.2 & $0.13 \%$ & 0.3 & 0.4 & $0.29 \%$ & 0.2 & 0.4 & $0.16 \%$ \\
\hline Tonsil & 0.1 & 0.1 & $0.04 \%$ & 0.0 & 0.1 & $0.05 \%$ & 0.0 & 0.0 & $0.00 \%$ \\
\hline Other oropharynx & 0.0 & 0.0 & $0.00 \%$ & 0.1 & 0.1 & $0.10 \%$ & 0.2 & 0.3 & $0.16 \%$ \\
\hline Nasopharynx & 0.1 & 0.1 & $0.04 \%$ & 0.0 & 0 & $0.05 \%$ & 0.2 & 0.2 & $0.16 \%$ \\
\hline Hypopharynx & 0.0 & 0.0 & $0.00 \%$ & 0.4 & 0.4 & $0.38 \%$ & 0.6 & 0.9 & $0.48 \%$ \\
\hline Pharynx unspec. & 0.0 & 0.0 & $0.00 \%$ & 0.0 & 0.0 & $0.05 \%$ & 0.0 & 0.0 & $0.00 \%$ \\
\hline Esophagus & 0.9 & 1.2 & $0.65 \%$ & 1.2 & 1.9 & $1.25 \%$ & 1.1 & 1.6 & $0.96 \%$ \\
\hline Stomach & 2.3 & 3.2 & $1.73 \%$ & 1.2 & 1.8 & $1.25 \%$ & 1.9 & 3.1 & $1.60 \%$ \\
\hline Small intestine & 0.3 & 0.5 & $0.22 \%$ & 0.4 & 0.6 & $0.43 \%$ & 0.6 & 0.9 & $0.48 \%$ \\
\hline Colon & 3.0 & 4.2 & $2.30 \%$ & 2.2 & 3.2 & $2.31 \%$ & 2.4 & 3.5 & $2.08 \%$ \\
\hline Rectum & 0.9 & 1.0 & $0.65 \%$ & 1.0 & 1.2 & $1.01 \%$ & 0.7 & 1.3 & $0.64 \%$ \\
\hline Anus & 0.1 & 0.1 & $0.04 \%$ & 0.1 & 0.2 & $0.14 \%$ & 0.2 & 0.3 & $0.16 \%$ \\
\hline Liver & 21.6 & 32.6 & $16.37 \%$ & 8.6 & 13.7 & $8.95 \%$ & 6.0 & 8.7 & $5.12 \%$ \\
\hline Gallbladder and so forth & 0.5 & 0.5 & $0.35 \%$ & 0.6 & 0.9 & $0.58 \%$ & 1.9 & 3.1 & $1.60 \%$ \\
\hline Pancreas & 2.1 & 3.2 & $1.60 \%$ & 0.9 & 1.4 & $0.91 \%$ & 1.7 & 2.3 & $1.44 \%$ \\
\hline Nose, sinuses and so forth & 0.3 & 0.5 & $0.26 \%$ & 0.1 & 0.2 & $0.14 \%$ & 0.2 & 0.2 & $0.16 \%$ \\
\hline Larynx & 0.2 & 0.3 & $0.17 \%$ & 0.3 & 0.4 & $0.29 \%$ & 0.4 & 0.7 & $0.32 \%$ \\
\hline Trachea, Bronchus, Lung & 3.7 & 5.3 & $2.82 \%$ & 2.2 & 3.1 & $2.26 \%$ & 2.4 & 3.8 & $2.08 \%$ \\
\hline Other Thoracic organs & 0.6 & 0.8 & $0.43 \%$ & 0.5 & 0.7 & $0.48 \%$ & 0.0 & 0.0 & $0.00 \%$ \\
\hline Bone & 2.0 & 2.3 & $1.52 \%$ & 1.8 & 2.4 & $1.92 \%$ & 3.4 & 4.4 & $2.88 \%$ \\
\hline Melanoma of skin & 0.2 & 0.3 & $0.17 \%$ & 0.0 & 0.1 & $0.05 \%$ & 0.0 & 0.0 & $0.00 \%$ \\
\hline Other skin & 1.7 & 2.4 & $1.26 \%$ & 1.0 & 1.5 & $1.06 \%$ & 1.9 & 3.1 & $1.60 \%$ \\
\hline Mesothelioma & 0.3 & 0.3 & $0.22 \%$ & 0.2 & 0.3 & $0.24 \%$ & 0.4 & 0.7 & $0.32 \%$ \\
\hline Kaposi sarcoma & 0.0 & 0.0 & $0.00 \%$ & 0.0 & 0.1 & $0.05 \%$ & 0.0 & 0.0 & $0.00 \%$ \\
\hline Connective, Soft tissue & 2.3 & 2.6 & $1.78 \%$ & 0.4 & 0.6 & $0.38 \%$ & 1.9 & 2.2 & $1.60 \%$ \\
\hline Breast & 43.8 & 53 & $33.22 \%$ & 25.8 & 35.6 & $26.84 \%$ & 45.3 & 64.5 & $38.72 \%$ \\
\hline Vulva & 0.0 & 0.0 & $0.00 \%$ & 0.3 & 0.4 & $0.34 \%$ & 0.0 & 0.0 & $0.00 \%$ \\
\hline Vagina & 0.1 & 0.2 & $0.09 \%$ & 0.1 & 0.2 & $0.14 \%$ & 0.6 & 1.0 & $0.48 \%$ \\
\hline Cervix Uteri & 1.7 & 2.4 & $1.26 \%$ & 1.0 & 1.5 & $1.06 \%$ & 0.6 & 0.9 & $0.48 \%$ \\
\hline Corpus Uteri & 0.6 & 0.9 & $0.43 \%$ & 0.6 & 0.9 & $0.67 \%$ & 1.7 & 2.9 & $1.44 \%$ \\
\hline Uterus unspec. & 3.7 & 5.3 & $2.77 \%$ & 1.0 & 1.3 & $1.06 \%$ & 2.4 & 3.8 & $2.08 \%$ \\
\hline Ovary & 5.1 & 6.4 & $3.90 \%$ & 3.6 & 5.0 & $3.75 \%$ & 7.1 & 10.2 & $6.08 \%$ \\
\hline Other female genital & 0.0 & 0.0 & $0.00 \%$ & 0.0 & 0.1 & $0.05 \%$ & 0.4 & 0.6 & $0.32 \%$ \\
\hline Placenta & 0.0 & 0.0 & $0.00 \%$ & 0.0 & 0.0 & $0.05 \%$ & 0.2 & 0.2 & $0.16 \%$ \\
\hline Kidney & 1.1 & 1.6 & $0.87 \%$ & 1.2 & 1.8 & $1.25 \%$ & 0.7 & 1.1 & $0.64 \%$ \\
\hline Renal pelvis & 0.2 & 0.3 & $0.17 \%$ & 0.2 & 0.3 & $0.19 \%$ & 0.2 & 0.2 & $0.16 \%$ \\
\hline Ureter & 0.0 & 0.0 & $0.00 \%$ & 0.0 & 0.0 & $0.00 \%$ & 0.0 & 0.0 & $0.00 \%$ \\
\hline Bladder & 3.7 & 5.9 & $2.77 \%$ & 3.1 & 4.9 & $3.27 \%$ & 3.6 & 5.7 & $3.04 \%$ \\
\hline Other urinary organs & 0.1 & 0.1 & $0.04 \%$ & 0.0 & 0.0 & $0.00 \%$ & 0.0 & 0.0 & $0.00 \%$ \\
\hline Eye & 0.1 & 0.1 & $0.04 \%$ & 0.3 & 0.5 & $0.34 \%$ & 0.2 & 0.2 & $0.16 \%$ \\
\hline Brain, Nervous tissue & 5.8 & 7.4 & $4.42 \%$ & 7.4 & 11.1 & $7.70 \%$ & 2.4 & 2.9 & $2.08 \%$ \\
\hline Thyroid & 5.1 & 5.4 & $3.90 \%$ & 1.6 & 2.1 & $1.64 \%$ & 3.6 & 4.2 & $3.04 \%$ \\
\hline Adrenal gland & 0.2 & 0.3 & $0.17 \%$ & 0.2 & 0.3 & $0.24 \%$ & 0.2 & 0.2 & $0.16 \%$ \\
\hline Other endocrine & 0.1 & 0.0 & $0.04 \%$ & 0.5 & 0.7 & $0.53 \%$ & 0.2 & 0.2 & $0.16 \%$ \\
\hline Hodgkin disease & 1.0 & 0.7 & $0.74 \%$ & 1.0 & 1.0 & $1.01 \%$ & 0.9 & 0.9 & $0.80 \%$ \\
\hline
\end{tabular}


TABLE 7: Continued.

\begin{tabular}{|c|c|c|c|c|c|c|c|c|c|}
\hline \multirow{3}{*}{ Primary site } & \multirow{2}{*}{\multicolumn{3}{|c|}{$\begin{array}{c}\text { Lower Egypt } \\
2009-2011\end{array}$}} & \multirow{2}{*}{\multicolumn{3}{|c|}{$\begin{array}{c}\text { Middle Egypt } \\
2009\end{array}$}} & \multirow{2}{*}{\multicolumn{3}{|c|}{$\begin{array}{c}\text { Upper Egypt } \\
2008\end{array}$}} \\
\hline & & & & & & & & & \\
\hline & Crude & ASR & $\%$ & Crude & ASR & $\%$ & Crude & ASR & $\%$ \\
\hline Non-Hodgkin lymphoma & 5.4 & 6.7 & $4.11 \%$ & 4.2 & 5.8 & $4.43 \%$ & 2.6 & 3.8 & $2.24 \%$ \\
\hline Immunoproliferative dis. & 0.0 & 0.0 & $0.00 \%$ & 0.0 & 0.0 & $0.00 \%$ & 0.0 & 0.0 & $0.00 \%$ \\
\hline Multiple myeloma & 0.7 & 0.9 & $0.52 \%$ & 0.1 & 0.3 & $0.14 \%$ & 0.2 & 0.0 & $0.16 \%$ \\
\hline Lymphoid leukemia & 1.0 & 1.1 & $0.74 \%$ & 1.2 & 1.6 & $1.25 \%$ & 1.5 & 1.6 & $1.28 \%$ \\
\hline Myeloid Leukemia & 0.9 & 1.1 & $0.65 \%$ & 1.7 & 2.0 & $1.78 \%$ & 2.2 & 3.3 & $1.92 \%$ \\
\hline Leukemia unspec. & 1.8 & 2.4 & $1.34 \%$ & 1.6 & 2.0 & $1.68 \%$ & 1.9 & 2.3 & $1.60 \%$ \\
\hline Other \& unspecified & 5.9 & 8.2 & $4.46 \%$ & 14.3 & 15.5 & $14.86 \%$ & 9.2 & 12.9 & $7.84 \%$ \\
\hline All sites Total & 131.7 & 173.3 & $100.00 \%$ & 95.9 & 132.1 & $100.00 \%$ & 116.9 & 167.1 & $100.00 \%$ \\
\hline All sites but $\mathrm{C} 44^{\#}$ & 130.1 & 170.9 & $98.74 \%$ & 94.9 & 130.7 & $98.94 \%$ & 115.1 & 163.9 & $98.40 \%$ \\
\hline
\end{tabular}

\#Incidence rates do not include nonmelanoma skin cancer.

TABLE 8: Proportions and incidence rates of the most frequently observed cancers in the 3 regions of Egypt.

\begin{tabular}{|c|c|c|c|c|c|c|c|c|c|c|c|c|}
\hline & \multicolumn{4}{|c|}{$\begin{array}{c}\text { Lower Egypt } \\
\text { 2009-2011 }\end{array}$} & \multicolumn{4}{|c|}{$\begin{array}{l}\text { Middle Egypt } \\
2009\end{array}$} & \multicolumn{4}{|c|}{$\begin{array}{c}\text { Upper Egypt } \\
2008\end{array}$} \\
\hline & Site & $\%$ & Crude rate & ASR & Site & $\%$ & Crude rate & ASR & Site & $\%$ & Crude rate & ASR \\
\hline \multirow{5}{*}{ Males } & Liver & 41.7 & 57.8 & 81.0 & Liver & 20.4 & 22.4 & 37.6 & Bladder & 12.6 & 12.2 & 19.3 \\
\hline & Bladder & 8.8 & 12.2 & 19.0 & Bladder & 14.2 & 15.6 & 26.4 & Liver & 11.8 & 11.5 & 17.5 \\
\hline & NHL & 6.0 & 8.3 & 10.3 & Brain ${ }^{\#}$ & 7.3 & 8.0 & 12.5 & Lung $^{\# \#}$ & 7.6 & 7.4 & 11.5 \\
\hline & Lung $^{\# \#}$ & 5.5 & 7.6 & 10.1 & Lung $^{\# \#}$ & 5.8 & 6.3 & 10.8 & Leukemia & 6.1 & 6.0 & 6.7 \\
\hline & Prostate & 4.8 & 6.7 & 11.7 & Leukemia & 4.9 & 5.4 & 6.7 & Prostate & 5.9 & 5.7 & 9.2 \\
\hline \multirow{5}{*}{ Females } & Breast & 33.2 & 43.8 & 53.0 & Breast & 26.8 & 25.8 & 35.6 & Breast & 38.7 & 45.3 & 64.5 \\
\hline & Liver & 16.4 & 21.6 & 32.6 & Liver & 8.9 & 8.6 & 13.7 & Ovary & 6.1 & 7.1 & 10.2 \\
\hline & Brain ${ }^{\#}$ & 4.4 & 5.8 & 7.4 & Brain ${ }^{\#}$ & 7.7 & 7.4 & 11.1 & Liver & 5.1 & 6.0 & 8.7 \\
\hline & NHL & 4.1 & 5.4 & 6.7 & Leukemia & 4.7 & 4.5 & 5.6 & Leukemia & 4.8 & 5.6 & 7.2 \\
\hline & Thyroid & 3.9 & 5.1 & 5.4 & NHL & 4.4 & 4.2 & 5.8 & Uterus & 3.5 & 4.1 & 6.7 \\
\hline \multirow{5}{*}{ Both Sexes } & Liver & 29.6 & 40.1 & 56.8 & Liver & 15.2 & 15.6 & 25.7 & Breast & 21.6 & 23.1 & 33.2 \\
\hline & Breast & 16.1 & 21.7 & 26.9 & Breast & 12.4 & 12.8 & 18.1 & Liver & 8.2 & 8.8 & 13.1 \\
\hline & Bladder & 5.9 & 8.0 & 12.5 & Bladder & 9.2 & 9.5 & 15.7 & Bladder & 7.4 & 7.9 & 12.5 \\
\hline & NHL & 5.1 & 6.9 & 8.5 & Brain $^{\#}$ & 7.5 & 7.7 & 11.8 & Leukemia & 5.4 & 5.7 & 7.0 \\
\hline & Brain $^{\#}$ & 4.5 & 6.0 & 7.8 & Leukemia & 4.8 & 4.9 & 6.2 & Lung ${ }^{\# \#}$ & 4.6 & 4.9 & 7.7 \\
\hline
\end{tabular}

${ }^{\#}$ Includes brain and nervous system tumors.

\#\# Includes trachea, bronchus and lung tumors.

to the high prevalence of hepatitis $\mathrm{C}$ viral infection (HCV), which is one of the highest prevalence rates worldwide $[34,35]$. The distribution of liver cancer in the 3 regions followed the distribution of $\mathrm{HCV}$, which is more frequent in Nile delta with decreasing prevalence going south [34]. The main risk factor for bladder cancer in Egypt was urinary Schistosomiasis which was more frequent in Upper Egypt and its prevalence decreased when going north [34]. Despite control of Schistosomiasis, its effect on bladder cancer needs time to disappear. Another difference between the 3 regions was the proportion of non-Hodgkin lymphoma that was distributed in a pattern similar to that of liver cancer $[36,37]$.

Among females, the pattern in Lower, Middle, and Upper Egypt was dominated by the high frequency of breast cancer (33.8\%, $26.8 \%$ and $38.7 \%$ resp.) and liver cancer $(16.4 \%, 8.9 \%$ and $5.1 \%$ resp.). This pattern of liver cancer was similar to that of males with similar relation to the prevalence of $\mathrm{HCV}$. Other differences in site distribution between the 3 regions will be detailed in a separate publication [38].

The national age standardized incidence rates for all cancers in Egypt, excluding nonmelanoma skin cancer, were 175.9/100,000 for males, 157.0/100,000 for females, and $166.6 / 100,000$ for both sexes. The age-standardized rates were intermediate between the rates of more and less developed countries $[33,39,40]$. For both sexes, the rates for all cancers excluding nonmelanoma skin cancer were 268.3/100,000 for more developed countries and 147.7/100,000 for less developed countries compared to 166.6/100,000 in Egypt. For males, the age-standardized rates were $308.7 / 100,000$ for more developed countries and 163.0/100,000 for less developed countries compared to 175.9/100,000 in Egypt. The rates of females were $240.6 / 100,000$ in more developed countries and 135.8/100,000 in less developed countries compared to 157.0/100,000 for Egypt. 


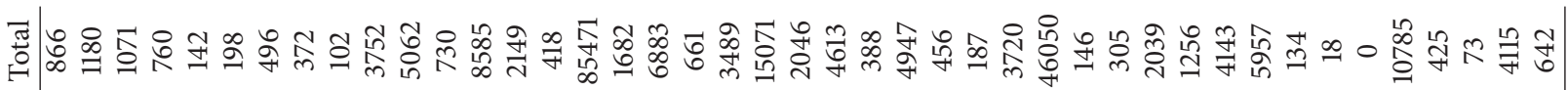

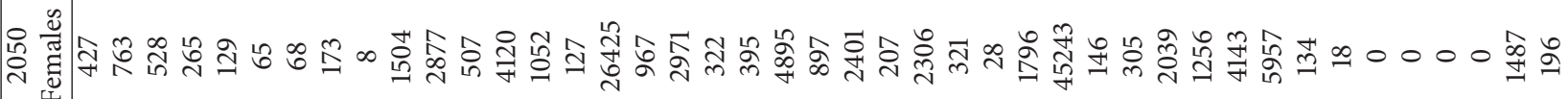

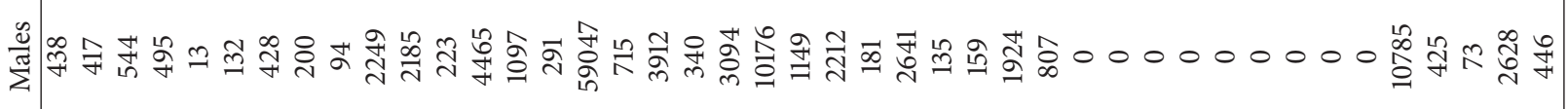

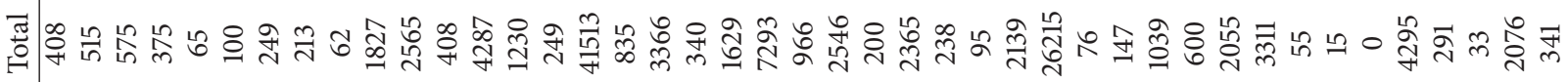

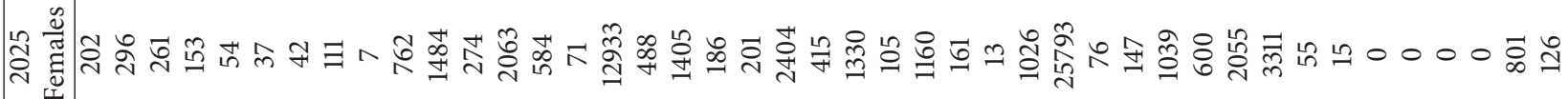

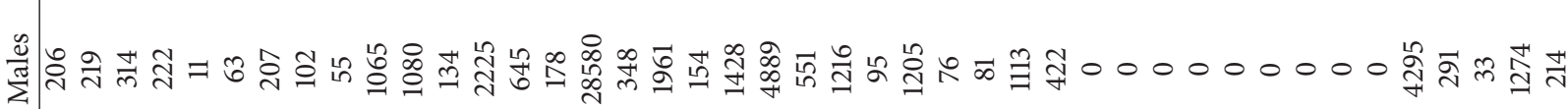

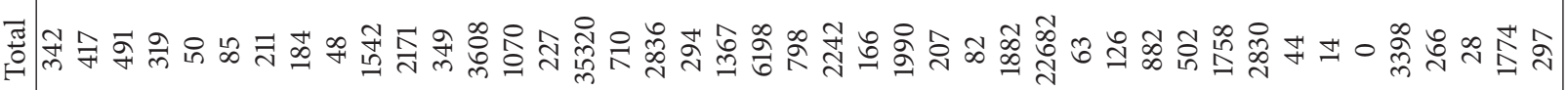

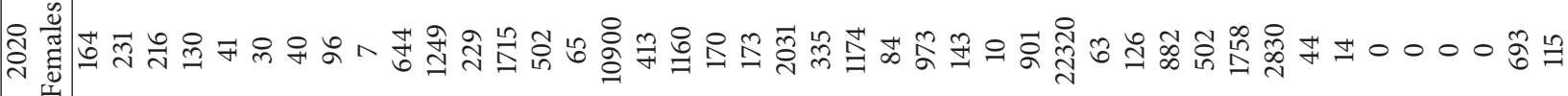

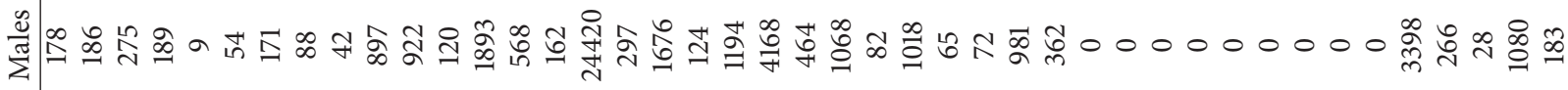

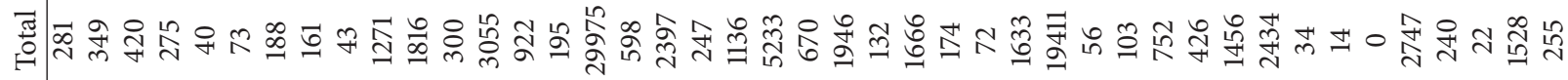

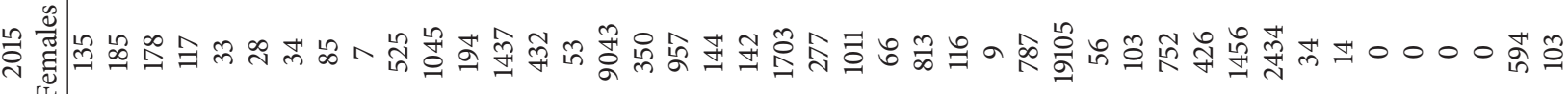

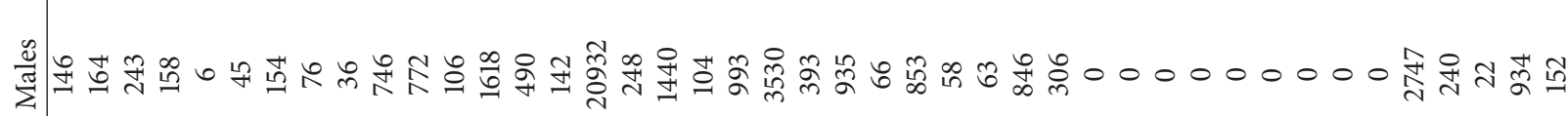

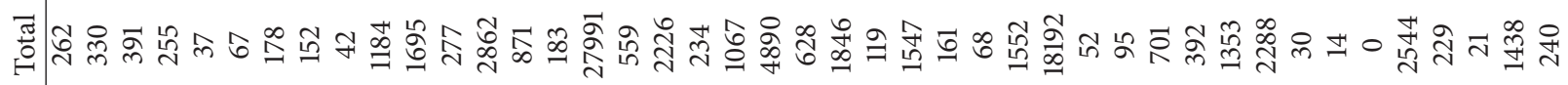

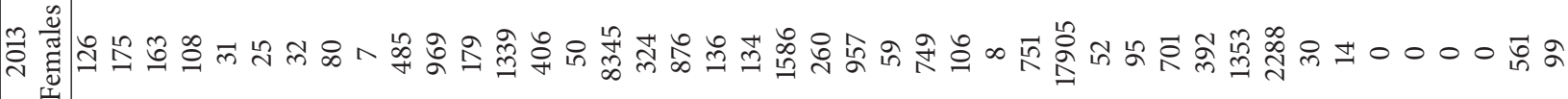

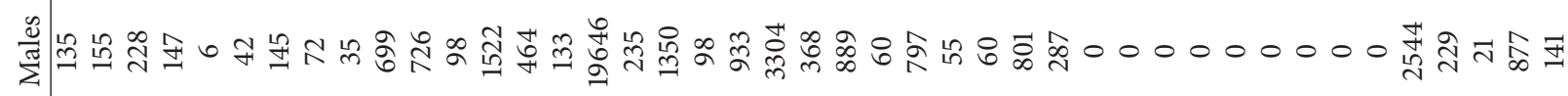

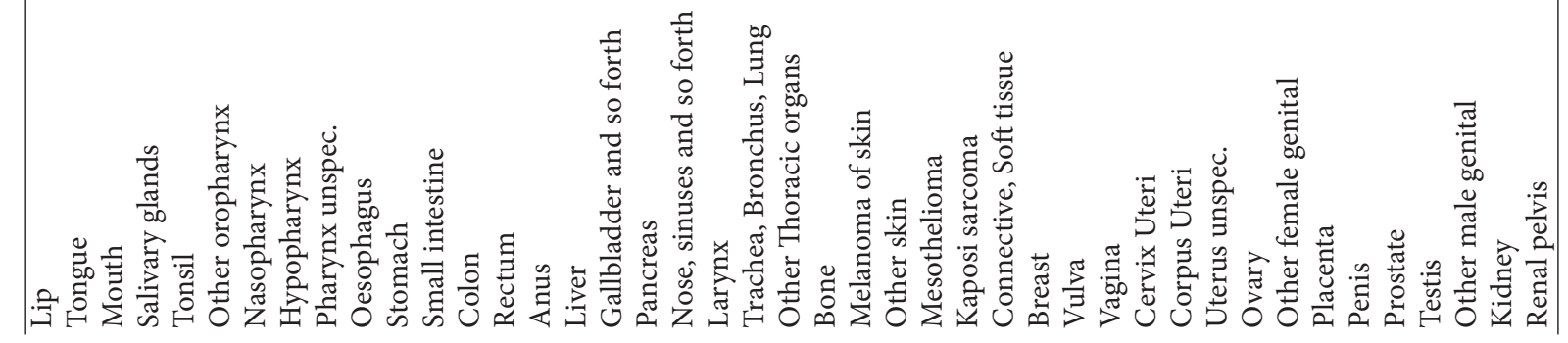




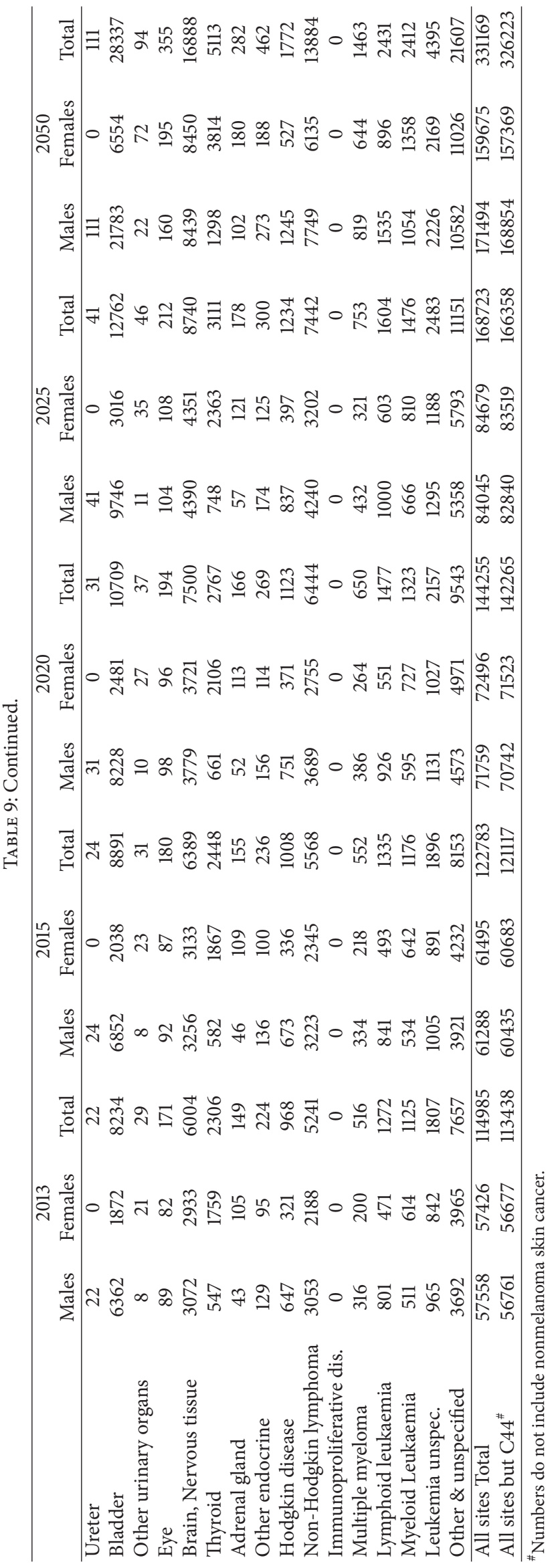


TABLE 10: Estimated cancer incidence in the period 2013-2050 and causes of increase.

\begin{tabular}{|c|c|c|c|c|c|}
\hline & 2013 & 2015 & 2020 & 2025 & 2050 \\
\hline Estimated population & $85294388(100 \%)$ & $88487396(103.7 \%)$ & 96260017 (112.9\%) & 103742157 (121.6\%) & $137872522(161.6 \%)$ \\
\hline Number of cases ${ }^{\# 1}$ & 114985 & $122783(106.8 \%)$ & $144255(125.5 \%)$ & $168723(146.7 \%)$ & $331169(288.0 \%)$ \\
\hline $\begin{array}{l}\text { Increased cases from } \\
2013^{\# 2}\end{array}$ & & $7798(6.8 \%)$ & $29270(25.5 \%)$ & $53738(46.7 \%)$ & $216184(188.0 \%)$ \\
\hline $\begin{array}{l}\text { Increased cases due to } \\
\text { population growth }\end{array}$ & & 4303 & 14783 & 24869 & 70880 \\
\hline $\begin{array}{l}\text { Increased cases due to } \\
\text { population structure } \\
\text { change }^{\# 4}\end{array}$ & & 3494 & 14487 & 28869 & 145304 \\
\hline $\begin{array}{l}\% \text { Increase due to } \\
\text { population growth }\end{array}$ & & $55.20 \%$ & $50.50 \%$ & $46.28 \%$ & $32.79 \%$ \\
\hline
\end{tabular}

N.B.

${ }^{\# 1}$ Number of expected cases depending on 2013 rates of incidence.

\#2 Number of increased cases from 2013 number of cases.

\#3 Number of increased cases (from 2013) that is attributed to increase in population number (population growth).

\#4 Number of increased cases (from 2013) that is attributed to change in population structure (aging of population) and not to population growth.

${ }^{\# 5}$ Percent of increased number of cases (from 2013) that can be attributed to population growth only (not due to change in population structure).

The model used in our study revealed the seriousness of the liver cancer that ranked first among cancers in males (33.6\%) and next to breast cancer. Among females the proportion of breast cancer was $32.0 \%$ followed by liver cancer (13.5\%). The high prevalence of HCV especially genotype IV would explain this high incidence $[34,35]$. The agestandardized rates for liver cancer for both genders were $5.4 / 100,000$ in more developed countries, $12.0 / 100,000$ in less developed countries compared to 43.6/100,000 in Egypt. Among males the rates were 8.6/100,000 in more developed countries, 17.8/100,000 in less developed countries compared to $61.8 / 100,000$ in Egypt. Among females, the rates were 2.7/100,000 (more developed), 6.6/100,000 (less developed), and 24.4/100,000 (Egypt).

Incidence rate of bladder cancer that ranked next to liver cancer in males was also high. The age-standardized rates are 16.9/100,000 (more developed) and 5.3/100,000 (less developed) compared to 21.1/100,000 in Egypt. Breast cancer was the most frequent cancer among females. The age-standardized rates are 74.1/100,000 (more developed), 31.3/100,000 (less developed), and 48.8/100,000 (Egypt). Analysis of individual sites of cancers will be detailed in a separate publication [38].

Applying the model over successive years for the projected populations showed an increase in number of incident cases from approximately 115,000 patients in 2013 to more than 331,000 in 2050, almost 3-fold increase. The fraction of increase due to population growth gradually decreased over the years with a corresponding increase in the fraction due to demographic transition with ageing of the population. The cancer problem in Egypt would thus be expected to continue simply due to the inevitable ageing of the population with better standards of health care (Table 10).

Rates estimated by the model developed for the study were based on certain assumptions that should be considered in interpretation of results. These assumptions were: (a) constant age-specific rates during the study period; (b) populations of Greater Cairo and Alexandria would be considered a mosaic of the 3 registration regions and would affect the number of incident cases, and not rates; and (c) exclusion of frontier governorates (3.3\% of total population of Egypt) that need special studies to get reliable cancer statistics.

\section{Conclusion}

These results are the first ever published incidence rates for Egypt on a national and regional level and clearly demonstrated the seriousness of the cancer problem of Egypt with age-adjusted incidence rates approaching those of the more developed countries. Liver cancer is a serious if not the most serious cancer problem in Egypt. Nonetheless, these rates should be carefully interpreted being based on a short initial phase of registration and a mathematical model that used regional incidence rates.

\section{Appendix}

\section{Statistical Formulas Used in the Analysis}

Step 1 (calculation of regional and national incident cases for census year 2006/sex). (1) Number of incident cancer cases $C$ in age group $x /$ region $i$ where $r$ is incidence rate and $w$ is population size:

$$
C_{x i}=r_{x i g} * w_{x i g} .
$$

(2) Total incident cases in region $i: C_{i}=\sum C_{x i}$.

(3) Total incident cases in the 3 regions $G: C_{G}=\sum C_{i}$ where $I=1-3$.

(4) Incident cases in total Egypt $M$ :

$C_{M}=\sum C_{G} *\left(W_{M} / W_{G}\right)$ where $W$ is 2006 population.

(5) Calculation of national age specific incidence rates $r_{x M}=\sum C_{x i} / W_{x i}$ for the 3 regions. 
Step 2 (calculation of regional and national incident cases for a given year/sex). The same procedure was followed applying $r_{x M}$ calculated above to the population of the year under study.

Step 3 (future projections). For estimation of incident cancer in a specific year till 2050, the national age specific incidence rates by sex were applied to the corresponding population structure [41]. This estimated number would be due to population growth and demographic change with aging of the population. The fraction due to population growth could be calculated using corresponding population sizes. The remainder of increase in number would be due mainly to demographic change.

\section{List of Abbreviations}

ASIR: Age specific incidence rate

ASR: Age standardized rate

DCO: Death certificate only

HCV: Hepatitis $\mathrm{C}$ virus

IARC: International Agency for Research on Cancer

ICD-10: International Statistical Classification of Diseases and related health problems, 10th revision

NCRP: National Cancer Registry Program of Egypt

NHL: Non-Hodgkin Lymphoma

SEER: Surveillance, Epidemiology, and End Results Program.

\section{Conflict of Interests}

The authors declare that there is no conflict of interests regarding the publication of this paper.

\section{Acknowledgments}

The authors acknowledge the important role played by staff of the Ministry of Communication and Information technology specially Dr. Hesham El Deeb engineers El-Sayed Abdelwahid and Mohamed Hamid who were actively behind success of the registry. The dedication of data managers who supervised peripheral registries' activities during the initial phase of registration, namely, Drs. Amir Bishara (Aswan), Hassan Afifi (Minya), Tarek Heikal (Damietta), and Professor Nelly Alieldin (National Cancer Institute, Cairo University) is also acknowledged. Furthermore, this work would have not been accomplished without the remarkable effort of abstractors, coders, and supporting staff in participating registries.

\section{References}

[1] R. Dolbey and A. W. Mooro, "The incidence of cancer in Egypt: an analysis of 671 cases," The Lancet, vol. 203, no. 5247, pp. 587$590,1924$.
[2] R. Bedwani, F. El-Khwsky, E. Reganathan et al., "Epidemiology of bladder cancers in Alexandria, Egypt: tobacco smoking," International Journal of Cancer, vol. 73, pp. 64-67, 1997.

[3] W. Abou-Zeid, F. El-Khwsky, S. Mokhtar, M. Sherif, and N. Mahdy, "Descriptive epidemiology and multivariate survival analysis of oral and pharyngeal malignancies in Alexandria," Journal of the Medical Research Institute, vol. 27, no. 4, pp. 262270, 2006.

[4] I. El-Attar, Cancer statistics, NCI, 2004, Department of Biostatics and Epidemiology, NCI, Cairo, Egypt, 2005, http://www.nci .cu.edu.eg/lectures/NCI2004.ppt.

[5] M. Sherif and A. S. Ibrahim, The Profile of Cancer in Egypt, Cairo University, The National Cancer Institute, The Cancer Registry for the Metropolitan Cairo Area (CRMCA), 1987.

[6] J. L. Young, "The hospital-based cancer registry," in Cancer Registration: Principles and Methods, O. M. Jensen, D. M. Parkin, R. MacLennan, C. S. Muir, and R. G. Skeet, Eds., IARC Scientific Publications No. 05, 1991.

[7] I. Silava, "Cancer epidemiology: principles and methods," in Chapter 17: The Role of Cancer Registries, pp. 385-403, International Agency for Research on Cancer, World Health Organization, Geneva, Switzerland, 1999.

[8] A. S. Ibrahim, H. Hussein, K. Ismail, A. Hablas, I. Abdel Bar, and M. Ramadan, Cancer Profile in Gharbiah-Egypt, Methodology and Results, 1999, Gharbiah Population-Based Cancer Registry (GPCR), Cairo, Egypt, 2003.

[9] A. S. Ibrahim, I. A. Seif-Eldein, K. Ismail et al., "Cancer in Egypt, Gharbiah," Triennial Report of 2000-2002, Gharbiah Population-Based Cancer Registry, Middle East Cancer Consortium, Cairo, Egypt, 2007.

[10] M. P. Curado, B. Edwards, H. R. Shir et al., Eds., Cancer Incidence in Five Continents, vol. 9 of IARC Scientific Publication, no. 160, IARC, Lyon, France, 2007.

[11] M. P. Curado, B. Edwards, H. R. Shir et al., Eds., Cancer Incidence in Five Continents, Vol. X, IARC Press, Lyon, France, 2013, http://ci5.iarc.fr.

[12] K. A. Hirko, A. S. Soliman, A. Hablas et al., "Trends in breast cancer incidence rates by age and stage at diagnosis in gharbiah, Egypt, over 10 years (1999-2008)," Journal of Cancer Epidemiology, vol. 2013, Article ID 916394, 7 pages, 2013.

[13] A. A. Zeeneldin, M. Ramadan, A. A. Gaber, and F. M. Taha, "Clinico-pathological features of breast carcinoma in elderly Egyptian patients: a comparison with the non-elderly using population-based data," Journal of the Egyptian National Cancer Institute, vol. 25, no. 1, pp. 5-11, 2013.

[14] S. Dey, A. S. Soliman, A. Hablas et al., "Urban-rural differences in breast cancer incidence in Egypt (1999-2006)," Breast, vol. 19, no. 5, pp. 417-423, 2010.

[15] A. S. Soliman, M. Banerjee, A.-C. Lo et al., "High proportion of inflammatory breast cancer in the population-based cancer registry of gharbiah, Egypt," Breast Journal, vol. 15, no. 4, pp. 432-434, 2009.

[16] A. A. Zeeneldin, M. M. Saber, I. A. S. El-Din, and S. A. Frag, "Small intestinal cancers among adults in an Egyptian district: a clinicopathological study using a population-based cancer registry," Journal of the Egyptian National Cancer Institute, vol. 25, no. 3, pp. 107-114, 2013.

[17] M. M. Saber, A. A. Zeeneldin, M. A. Samra, and S. A. Farag, "Primary gastrointestinal lymphoma in an Egyptian district: a study using a population-based cancer registry," The Journal of the Egyptian National Cancer Institute, vol. 25, no. 2, pp. 95-101, 2013. 
[18] D. Veruttipong, A. S. Soliman, S. F. Gilbert et al., "Age distribution, polyps and rectal cancer in the egyptian population-based cancer registry," World Journal of Gastroenterology, vol. 18, no. 30, pp. 3997-4003, 2012.

[19] C. M. Herzog, S. Dey, A. Hablas et al., "Geographic distribution of hematopoietic cancers in the nile delta of Egypt," Annals of Oncology, vol. 23, no. 10, pp. 2748-2755, 2012.

[20] S. A. Fedewa, A. S. Soliman, K. Ismail et al., "Incidence analyses of bladder cancer in the Nile delta region of Egypt," Cancer Epidemiology, vol. 33, no. 3-4, pp. 176-181, 2009.

[21] S. Dey, A. Hablas, I. A. Seifeldin et al., "Urban-rural differences of gynaecological malignancies in Egypt (1999-2002)," BJOG, vol. 117, no. 3, pp. 348-355, 2010.

[22] National Cancer Registry Program of Egypt, http://www .cancerregistry.gov.eg/.

[23] DEPedits $@$, “Conversion and Check Programs for Cancer Registries software," http://www.encr.eu/index.php/downloads/ depedits.

[24] A. Fritz, C. Percy, A. Jack et al., International Classification of Diseases for Oncology, World Health Organization, 3rd edition, 2000.

[25] "Standardized Incidence Ratio and Confidence Limits," http:// seer.cancer.gov/seerstat/WebHelp/Standardized_Incidence_ Ratio_and_Confidence_Limits.htm.

[26] Central Agency for Public Mobilization and Statistics (CAPMAS), http://www.capmas.gov.eg/.

[27] SEER Program Self Instructional Manual for Cancer Registries, Book 1: Objectives and Functions of Cancer Registries, SEER Program, 1999, edited by E. M. Shambaugh, M. A. Weiss, A. Fritz, M. Hurst, C. H. Johnson, M. A. Kruse, and J. Seiffert.

[28] IARC, Cancer Registration: Principles and Methods, vol. 95 of IARC Scientific Publication, International Agency for Research on Cancer, Lyon, France, 1991, O. M. Jensen, D. M. Parkin, R. MacLennan, C. S. Muir and R. Skeet, eds.

[29] List of SEER Registries, http://seer.cancer.gov/registries/terms .html.

[30] S. Eser, C. Yakut, R. Özdemir et al., "Cancer incidence rates in Turkey in 2006: a detailed registry based estimation," Asian Pacific Journal of Cancer Prevention, vol. 11, no. 6, pp. 1731-1739, 2010.

[31] A. S. Ibrahim and N. N. H. Mikhail, Eds., Egypt National Cancer Registry: Aswan Profile-2008, Publication Number RR1, National Cancer Registry Program of Egypt, 2010.

[32] H. Zeng, R. Zheng, S. Zhang, X. Zou, and W. Chen, "Female breast cancer statistics of 2010 in China: estimates based on data from 145 population-based cancer registries," Journal of Thoracic Disease, vol. 6, no. 5, pp. 466-470, 2014.

[33] J. Ferlay, I. Soerjomataram, M. Ervik et al., Globocan 2012: Estimated Cancer Incidence, Mortality and Prevalence Worldwide in 2012, vol. 1.0 of IARC CancerBase no. 11, International Agency for Research on Cancer, Lyon, France, 2010, http://globocan.iarc .fr/.

[34] S. Ezzat, M. Abdel-Hamid, S. Abdel-Latif Eissa et al., "Associations of pesticides, HCV, HBV, and hepatocellular carcinoma in Egypt," International Journal of Hygiene and Environmental Health, vol. 208, no. 5, pp. 329-339, 2005.

[35] M. Abdel-Hamid, M. El-Daly, V. Molnegren et al., "Genetic diversity in hepatitis $\mathrm{C}$ virus in Egypt and possible association with hepatocellular carcinoma," Journal of General Virology, vol. 88, no. 5, pp. 1526-1531, 2007.
[36] K. D. Cowgill, C. A. Loffredo, S. A.-L. Eissa et al., "Casecontrol study of non-Hodgkin's lymphoma and hepatitis C virus infection in Egypt," International Journal of Epidemiology, vol. 33, no. 5, pp. 1034-1039, 2004.

[37] H. Farawela, M. Khorshied, I. Shaheen et al., "The association between hepatitis $\mathrm{C}$ virus infection, genetic polymorphisms of oxidative stress genes and B-cell non-Hodgkin's lymphoma risk in Egypt," Infection, Genetics and Evolution, vol. 12, no. 6, pp. 1189-1194, 2012.

[38] A. S. Ibrahim, N. N. H. Mikhail, H. Khaled et al., "Cancer incidence in Egypt: a closer look to registry results," In press.

[39] P. Boyle and B. Levin, Eds., World Cancer Report 2008, IARC, Lyon, France, 2008.

[40] F. Bray, A. Znaor, P. Cueva et al., Planning and Developing Population-based Cancer Registration in Low-and Middle-Income Settings, IARC, 2014.

[41] United States Census Bureau, International Data Base, http:// www.census.gov/population/international/data/idb/informationGateway.php. 


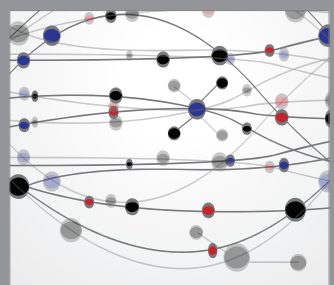

The Scientific World Journal
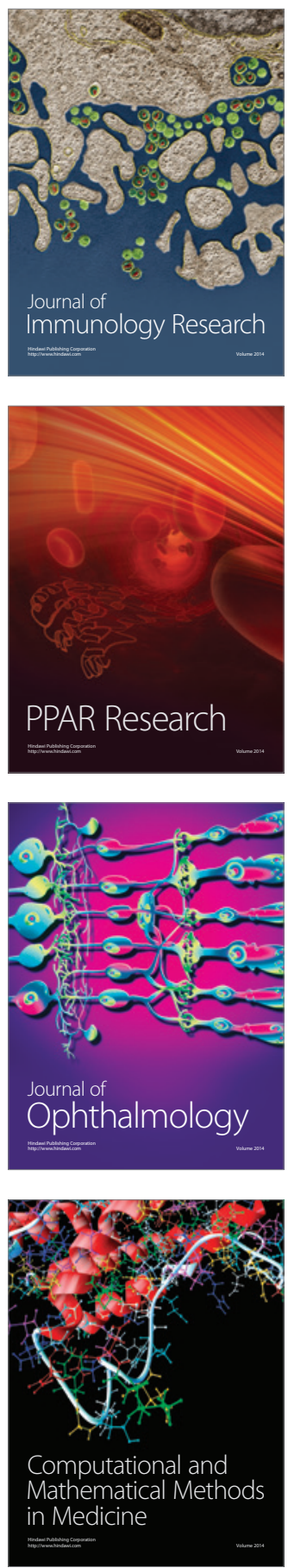

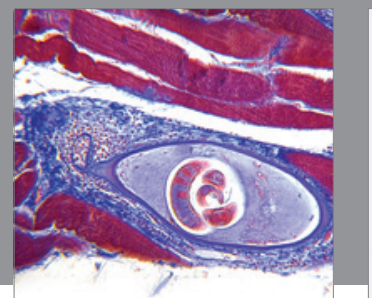

Gastroenterology

Research and Practice
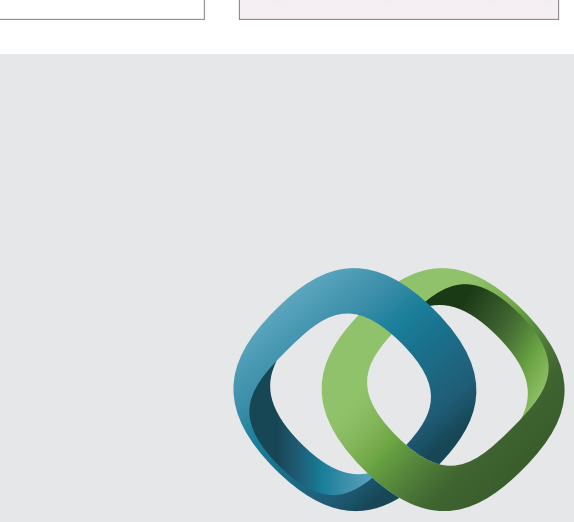

\section{Hindawi}

Submit your manuscripts at

http://www.hindawi.com
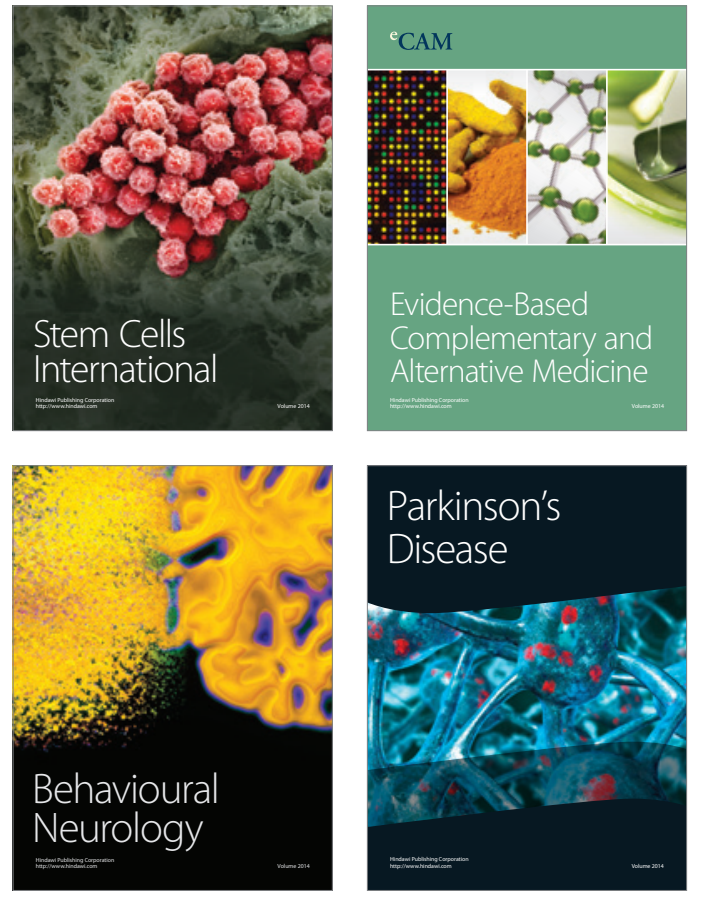
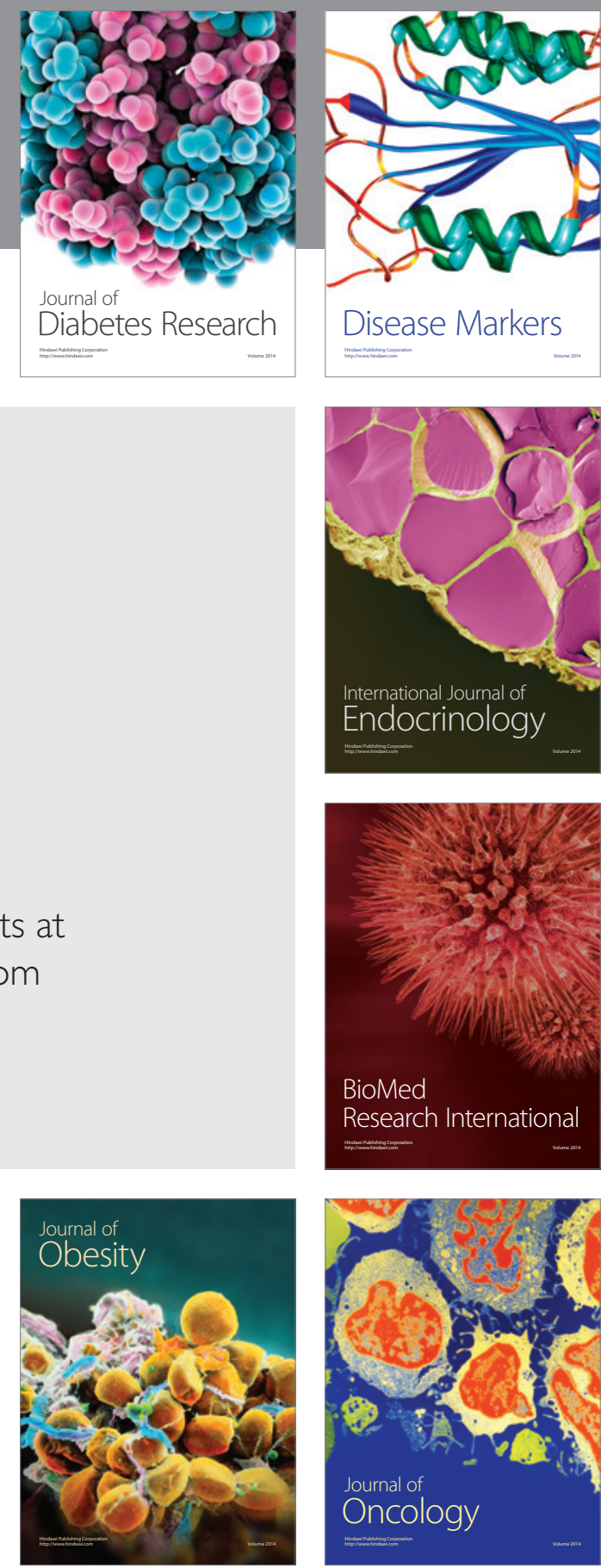

Disease Markers
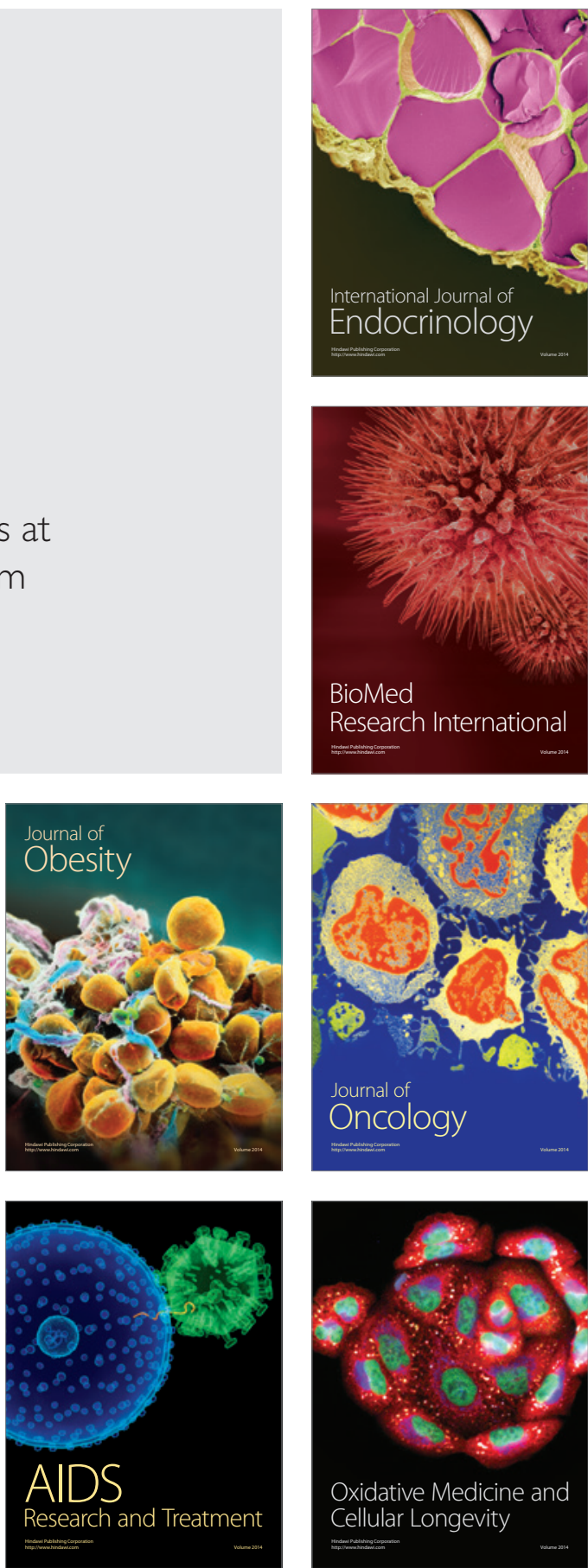